\title{
A Filosofia da Liberdade na Saga de Filmes Star Wars - Parte $2^{*}$
}

\author{
Alex Catharino**
}

\begin{abstract}
Resumo: O artigo analisa a Filosofia Moral e a Teoria Política que permeiam a saga de filmes Guerra nas Estrelas, do cineasta George Lucas. O autor relaciona a queda da personagem Anakin Skywalker com a ascensão do Império Galáctico e discute alguns temas da estória que podem ser apropriadas como metáforas explicativas de algumas propostas teóricas da Escola Austríaca de Economia, em especial das ideias de Ludwig von Mises e de F. A Hayek.
\end{abstract}

Palavras-Chave: Crítica Cinematográfica, Filosofia da Cultura, Ética, Liberdade, Democracia, Intervencionismo, Guerra nas Estrelas.

\section{The Philosophy of Liberty in the Star Wars Movies - Part 2}

\begin{abstract}
The article analyzes the Moral Philosophy and the Political Theory in the Star Wars movies saga, created by the moviemaker George Lucas. The author relates Anakin Skywalker fall with the ascension of the Galactic Empire and discusses some of the story issues that may be appropriated as metaphoric explanations of some theoretical proposals of the Austrian School of Economics, especially Ludwig von Mises' and F. A. Hayek's ideas.
\end{abstract}

Keywords: Film Criticism, Philosophy of Culture, Ethics, Liberty, Democracy, Interventionism, Star Wars.

Classificação JEL: B53, Z1

\footnotetext{
* O presente artigo é a segunda e última parte da versão revisada e ampliada do texto da palestra de mesmo título apresentada, em 7 de setembro de 2013, como parte da programação da II Conferência Nacional dos Estudantes Pela Liberdade (EPL), realizada, entre os dias 7 e 8 de setembro de 2013, em Belo Horizonte, MG. A primeira parte do ensaio foi publicada na edição anterior (Volume II, Número 1) de MISES: Revista Interdisciplinar de Filosofia, Direito e Economia.
}

\footnotetext{
${ }^{* *}$ Alex Catharino é vice-presidente executivo do Centro Interdisciplinar de Ética e Economia Personalista (CIEEP), gerente editorial dos periódicos COMMUNIO: Revista Internacional de Teologia e Cultura e MISES: Revista Interdisciplinar de Filosofia, Direito e Economia, e pesquisador residente do Russell Kirk Center for Cultural Renewal, em Mecosta, Michigan, nos EUA. Cursou a graduação em História na Universidade Federal do Rio de Janeiro (UFRJ) e fez estudos nas áreas de História, Arqueologia, Paleografia, Filosofia, Teologia, Literatura, Economia e Ciência Política em diferentes instituições no Brasil, EUA, Portugal, Itália, Argentina, Colômbia e Uruguai. Foi visiting fellow da Atlas Economic Research Foundation, em Washington, D.C., nos EUA. É autor de inúmeros artigos publicados em diferentes periódicos acadêmicos, bem como do capítulo "Origens e Desenvolvimento do Liberalismo Clássico" no livro Ensaios sobre Liberdade e Prosperidade (UNA Editoria, 2001), dos verbetes "Eric Voegelin (1901-1985)", "Liberalismo" e "Russell Kirk (1918-1994)" no Dicionário de Filosofia Política (Editora UNISINOS, 2010), dos estudos introdutórios "A Vida e a Imaginação de Russell Kirk" e "A Formação e o Desenvolvimento do Pensamento Conservador de Russell Kirk" para as edições brasileiras dos livros A Era de T. S. Eliot: A Imaginação Moral do Século XX (É Realizações, 2011) e A Política da Prudência (É Realizações, 2013) de Russell Kirk, e dos posfácios "Teologia e História na Reconstrução da Unidade Cristã" e "Em Busca da Cristandade Perdida" para as edições brasileiras dos livros A Formação da Cristandade (É Realizações, 2014) e A Divisão da Cristandade (É Realizações, 2014) de Christopher Dawson.

E-mail: alex@mises.org.br
} 


\section{III - A Queda de Anakin SKyWALKer e A AsCEnsão do IMPÉRIO GALÁCTICO}

Nos seis filmes que compõem as duas trilogias da saga Star Wars existe uma complexa tessitura política como pano de fundo de todos os acontecimentos. Isso é o que permite às personagens fazer escolhas morais distintas sobre o rumo da jornada a ser trilhada. Na trilogia mais recente, composta pelos filmes Episódio I: A Ameaça Fantasma, Episódio II: Ataque dos Clones e Episódio III: A Vingança dos Sith ${ }^{1}$, vemos como as manipulações do Senador Palpatine, na verdade um lorde Sith denominado Darth Sidious, serviram como meio para, de maneira democrática, tal personagem assumir o cargo de Chanceler Supremo da República Galáctica e, gradativamente, expandir o poder governamental sobre a sociedade até, finalmente, se tornar o Imperador e fazer o sistema político republicano ser substituída por uma monarquia absoluta com a instauração do Império Galáctico, fato que só se tornou possível após ele ter

${ }^{1}$ As referências aos filmes no presente artigo são feitas a partir das versões em DVDs duplos, com extras, nas seguintes edições:

StAR WARs: Episódio I - A AmEAÇA FANTASMA. Direção: George Lucas. Produção: Rick McCallum. Roteiro: George Lucas. Intérpretes: Liam Neeson, Ewan McGregor, Natalie Portman, Jake Lloyd, Ian McDiarmit e outros. Manaus: Twentieth Century Fox Home Entertainment Brasil, 2000. DVD (131 minutos).

StAR WARs: EPISÓdio II - AtAQUE DOS CLONES. Direção: George Lucas. Produção: Rick McCallum. Roteiro: Jonathan Hales e George Lucas. Intérpretes: Ewan McGregor, Natalie Portman, Hayden Christensen, Ian McDiarmit, Samuel L. Jackson, Christopher Lee e outros. Manaus: Twentieth Century Fox Home Entertainment Brasil, 2002. DVD (144 minutos).

StAR Wars: EpIsódio III - A VINGANÇA dos Sith. Direção: George Lucas. Produção: Rick McCallum. Roteiro: George Lucas. Intérpretes: Ewan McGregor, Natalie Portman, Hayden Christensen, Ian McDiarmit, Samuel L. Jackson, Christopher Lee e outros. Manaus: Twentieth Century Fox Home Entertainment Brasil, 2005. DVD (146 minutos). conseguido seduzir Anakin Skywalker para o Lado Negro da Força, transformando-o em Darth Vader, e, com a ajuda deste, ter destruído a Ordem dos Cavaleiros Jedi. A trilogia mais antiga, formada pelos longas-metragens Guerra nas Estrelas ou Episódio IV: Uma Nova Esperança, Episódio V: O Império Contra-Ataca, e Episódio VI: Retorno de Jedi $i^{2}$, apresenta um contexto de guerra civil no qual, por um lado, a Aliança Rebelde tenta restaurar a República e, por outro lado, o Império Galáctico busca expandir o poder sobre a sociedade, ao mesmo tempo em que procura esmagar a oposição dos rebeldes.

Tal como tentamos demonstrar nas primeiras seções do presente estudo ${ }^{3}$, o tema central dos seis filmes da série Star Wars não

${ }^{2}$ Dentre outras edições, os filmes dessa trilogia estão disponíveis, em DVDs simples, na seguinte edição:

Star Wars: Episódio IV - Uma Nova Esperança. Direção: George Lucas. Produção: Gary Kurtz. Roteiro: George Lucas. Intérpretes: Mark Hamill, Harrison Ford, Carrie Fisher, Peter Cushing, Alec Guinness e outros. Manaus: Twentieth Century Fox Home Entertainment Brasil, 2004. DVD (121 minutos).

Star Wars: Episódio V - O Império Contra-Ataca. Direção: Irvin Kershner. Produção: Gary Kurtz. Roteiro: Leigh Brackett e Lawrence Kasdan, baseado numa estória de George Lucas. Intérpretes: Mark Hamill, Harrison Ford, Carrie Fisher, Billy Dee Williams, Alec Guinness e outros. Manaus: Twentieth Century Fox Home Entertainment Brasil, 2004. DVD (124 minutos).

Star Wars: EpIsódio VI - O Retorno de Jedi. Direção: Richard Marquand. Produção: Howard G. Kazanjian. Roteiro: George Lucas e Lawrence Kasdan, baseado numa estória de George Lucas. Intérpretes: Mark Hamill, Harrison Ford, Carrie Fisher, Billy Dee Williams, Alec Guinness e outros. Manaus: Twentieth Century Fox Home Entertainment Brasil, 2004. DVD (131 minutos).

Esses DVDs foram lançados numa caixa com um quarto disco de extras, que inclui o documentário Empire of Dreams: The History of The Star Wars Trilogy [O Império dos Sonhos: A História da Trilogia Star Wars], dirigido por Edith Becker e Kevin Burns. Todas as referências aos filmes no presente artigo terão como base essa edição.

${ }^{3}$ CATHARINO, Alex. A Filosofia da Liberdade na Saga de Filmes Star Wars - Parte 1. MISES: Revista Interdisciplinar de Filosofia, Direito e Economia, Vol. II, No. 1 (jan.-jun. 2014): 259-77. 
é político, mas ético, visto que a narratologia desta saga trata principalmente da queda Anakin Skywalker ao ser seduzido pelo Lado Negro da Força, e da redenção de Darth Vader por intermédio da jornada de seu filho, Luke Skywalker. Sobre tal aspecto, o próprio cineasta norte-americano George Lucas, criador do universo Star Wars, fez o seguinte comentário:

Penso nestes filmes em grupos mais abrangentes. Penso neles como doze horas em seis partes. Foi um desafio interessante refazer a história de fundo. O Star Wars original foi criado para ser episódios IV, $\mathrm{V}$ e VI. Foi criado para ser algo que você pega no meio. $\mathrm{O}$ que eu mais queria dos temas anteriores [nos episódios I, II e III] é poder mostrar como o Império foi criado, como uma sociedade passa de democrática a ditatorial e ao mesmo tempo contrastar com uma história pessoal, sobre como uma pessoa boa torna-se má4.

Os aspectos centrais e os fundamentos teóricos da narratologia de Star Wars, com ênfasenomodocomoesta saga cinematográfica é um importante meio para a formação da Imaginação Moral, tal como entendida pelo pensador conservador norte-americano Russell Kirk (1918-1994)5, foi o objeto de um artigo acadêmico que publicamos há alguns anos, cujo propósito central foi destacar as possíveis representações alegóricas das relações entre ética e política na saga criada

\footnotetext{
${ }^{4}$ Declaração feita nos comentários de áudio ao filme Star Wars: Episódio II - O Ataque dos Clones.

${ }^{5}$ Acerca da concepção kirkeana de Imaginação Moral, ver: KIRK, Russell. A Imaginação Moral. Trad. Gustavo Santos e notas Alex Catharino. COMMUNIO: Revista Internacional de Teologia e Cultura, COMMUNIO: Revista Internacional de Teologia e Cultura, Vol. XVIII, No. 1 (Ed. 101 / Jan.-Mar. 2009): 103-19. Ver, também: GUROIAN, Vigen. A Imaginação Moral e os Contos de Fadas. Trad. e notas Márcia Xavier de Brito. COMMUNIO: Revista Internacional de Teologia e Cultura, Vol. XXVII, No. 1 (Ed. 97 / Jan.-Mar. 2008): 185-202; KIRK, Russell. A Era de T. S. Eliot: A Imaginação Moral do Século XX. Apr. Alex Catharino; Intr. Benjamin G. Lockerd Jr.; Trad. Márcia Xavier de Brito. São Paulo: É Realizações, 2011.
}

por George Lucas, defendendo a partir de tal apropriação as noções teológicas e filosóficas cristãs de que os problemas externos do ordenamento social encontram suas raízes nas desordens interiores da alma dos indivíduos ${ }^{6}$. A despeito de Star Wars ser, ao mesmo tempo, um drama mimético com aspectos trágicos e um drama espetacular de caráter lúdico e cômico que trata essencialmente da queda e redenção individual, ou seja, da ordem interna da existência, encontramos nos seis filmes da série inúmeras questões fundamentais de caráter externo relativas à moral social, à política e à economia, que como um baixo contínuo perpassa toda a composição, criando metáforas que podem ser apropriadas para fins pedagógicos. Neste particular, tal como já ressaltamos nas seções anteriores da primeira parte de nosso ensaio, as alegorias presentes no conjunto da criação artística de George Lucas podem ser utilizadas como exemplos ilustrativos de diversas propostas teóricas da Escola Austríaca de Economia, particularmente no entendimento da liberdade individual, tal como defendida por Ludwig von Mises (1881-1973), F. A. Hayek (1899-1992), Murray N. Rothbard (1926-1995) e outros epígonos dessa corrente de pensamento social7.

Alguns críticos podem acusar nossa interpretação de ser caudatária de uma prosélita visão de mundo ao afirmar que a saga Star

${ }^{6}$ CATHARINO, Alex. A Imaginação Moral em Star Wars. COMMUNIO: Revista Internacional de Teologia e Cultura, Vol. XVIII, No. 1 (Ed. 101 / Jan.Mar. 2009): 221-52.

7 Apadrinhamos que a melhor obra introdutória ao pensamento da Escola Austríaca de Economia, tanto pela sistematicidade quanto pela clareza, foi publicada originalmente em língua portuguesa, trata-se do seguinte livro: IORIO, Ubiratan Jorge. Ação, Tempo e Conhecimento: A Escola Austríaca de Economia. São Paulo: Instituto Ludwig von Mises Brasil, 2011. Para uma análise histórica bem estruturada dos aspectos significativos do pensamento dos principais expoentes dessa tradição intelectual, ver: CONSTANTINO, Rodrigo. Economia do Indivíduo: O Legado da Escola Austríaca. São Paulo: Instituto Ludwig von Mises Brasil, 2009. 
Wars apresenta determinados arquétipos universais, que, devido à amplitude simbólica, podem se conformar de modos distintos às diferentes concepções políticas, sendo vazias de conteúdo real e, por conseguinte, determinadas de acordo com as preferências subjetivas do analista. Outros arguidores podem rotular nossa investigação de despropositada, sustentando que a obra de George Lucas não passa de mero entretenimento popular, subordinado aos modismos tecnológicos de nossa época e voltado para as massas desprovidas de senso artístico de nossas sociedades de consumo, não possuindo, por esse motivo, nenhum fundamento teórico digno de análise. No entanto, a ensaísta e escritora norte-americana Camille Paglia corrobora nossa perspectiva ao defender que o criador de Star Wars é o maior artista de nosso tempo, "um épico cineasta que transformou as deslumbrantes novas tecnologias num gênero pessoal expressivo", visto que "ninguém reduziu a distância que separava a arte da tecnologia com maior êxito do que George Lucas"8. De modo perspicaz e desprovida dos preconceitos esnobes, que, infelizmente, contaminam as análises da maioria de nossos críticos contemporâneos, a autora reconhece que:

Lucas foi um visionário digital que profetizou e ajudou a moldar um sem número de avanços, como as imagens computadorizadas, a edição de filmes, a mixagem de sons e o desenho virtual dos cenários por computação; a cinematografia de alta definição; a transmissão por fibra ótica de jornais; a duplicação de filmes e sua distribuição digital; o som tipo stereo surround nos cinemas e nas residências; e os refinamentos nos gráficos, na interatividade e na música dos video games 9 .

Além destes inovadores aspectos técnicos, Camille Paglia ressalta o caráter

\footnotetext{
${ }^{8}$ PAGLIA, Camille. Imagens Cintilantes: Uma viagem através da arte desde o Egito até Star Wars. Trad. Roberto Leal Ferreira. Rio de Janeiro: Apicuri, 2014. p. 183.

${ }^{9}$ Idem. Ibidem. p. 184.
}

artístico do trabalho de George Lucas, destacando que:

A crítica à série Star Wars se concentrou em seus limitados papéis femininos e na abstenção de sexo; no número reduzido de atores negros e seus sotaques caricaturais, interpretados como racismo; e nos diálogos inexpressivos. Diz Lucas: "meus filmes estão essencialmente nas imagens": "tudo é visual". Ele encara os diálogos meramente como "um efeito sonoro, um ritmo, um coro vocal em meio à trilha sonora geral". Em sua estrutura, Star Wars se desenvolve como sequências dinâmicas de ação que se alternam com quadros panorâmicos, inclusive deslumbrantes paisagens urbanas, entrecruzadas por imenso tráfego aéreo. Lucas declarou: "não estou realmente interessado em enredos". E em outro lugar: "Para mim, o roteiro é só um caderno de esboços, só uma lista de anotações". Detalhes do roteiro (como a origem de uma cicatriz no rosto) são às vezes fornecidos fora dos filmes, no pantagruélico cosmos das séries de quadrinhos, video games, romances, manuais, action figures, kits plásticos para montar e sites na Internet sobre Star Wars. A orientação imagística de Lucas é inequívoca em sua declaração de missão: "os filmes são uma massa de objetos que se movem ao longo de uma ampla superfície". Sua principal tarefa, diz ele, é decidir onde, e por quanto tempo, o olho do espectador deve estar. Lucas chama a sua nova tecnologia digital de "uma nova cor": "é um jeito completamente diferente de fazer cinema. Hoje é pintura; não é mais fotografia" ${ }^{\prime 10}$.

Ao analisar o gênero e os fundamentos teóricos de Star Wars na primeira seção do presente ensaio, destacamos o caráter artístico desta criação de George Lucasao compararmos tais produções cinematográficas populares às tragédias de William Shakespeare (1564-1616) e às óperas de Wolfgang Amadeus Mozart $(1756-1791)^{11}$. Sustentamos tal assertiva

\footnotetext{
${ }^{10}$ Idem. Ibidem. p. 188.

${ }^{11}$ CATHARINO. A Filosofia da Liberdade na Saga de Filmes Star Wars - Parte 1. p. 270-72.
} 
escorados em uma percepção estética de Platão (427-347 a.C.) ${ }^{12}$ e nas teorias do crítico literário canadense Northrop Frye (19121991) ${ }^{13}$. Alicerçados na definição de herói trágico apresentada por Aristóteles (384-322 a.C. ${ }^{14}$ e na interpretação de "falha trágica" tal como descrita pelo roteirista norte-americano Christopher Vogler ${ }^{15}$, ao abordar a tragédia de Anakin Skywalker / Darth Vader na segunda seção dessas reflexões, enunciamos que este herói-vilão encarna de modo exemplar tal arquétipo, visto que a queda dessa personagem é oriunda de um vício intrínseco ao heróis clássicos em geral, mas que no caso específico de Anakin se manifesta na soberba, na vanglória, na tibieza, na temeridade, no ciúme e na ira que são manipulados por Palpatine para seduzir o herói e transformálo no vilão, ao mesmo tempo em que, movido pela "vontade de poder", assume o controle político absoluto da República Galáctica e instaura o Império ${ }^{16}$.

Mesmo sendo dotado das máculas inerentes ao arquétipo do herói trágico, a motivação original de Anakin Skywalker era boa, pois visava tanto a proteção da pessoa amada, a Senadora Padmé Amidala, quanto a manutenção da ordem social, dilacerada, internamente, pela corrupção política e, externamente, pelo conflito com as forças

\footnotetext{
${ }^{12}$ PLATÃO. O Banquete, 223b. Em língua portuguesa, ver: PLATÃO. O Banquete. Trad. José Cavalcante de Souza. In: Diálogos: Banquete - Fédon - Sofista Político. São Paulo: Abril Cultural, 1972. (Coleção "Os Pensadores", Volume III: Platão). p. 59.

13 FRYE, Northrop. Anatomia da Crítica: Quatro Ensaios. Pref. Robert D. Denham; Pref. Ed. Br. João Cezar de Castro Rocha; Trad. Marcus de Martini. São Paulo: É Realizações, 2014. p. 448-51.

${ }^{14}$ ARISTÓTELES. Poética, 1420a. Em língua portuguesa, ver: ARISTÓTELES. Poética. Trad. Eudoro de Souza. São Paulo: Abril Cultural, 1973. (Coleção “Os Pensadores", Volume IV: Aristóteles). p. 246.

${ }^{15}$ VOGLER, Christopher. A Jornada do Escritor: Estruturas Míticas para Escritores. Pref. e trad. Ana Maria Machado. Rio de Janeiro: Nova Fronteira, 2a Ed., 2006.

${ }^{16}$ CATHARINO. A Filosofia da Liberdade na Saga de Filmes Star Wars - Parte 1. p. 272-75.
}

separatistas. Todavia, o erro da personagem estava na escolha de meios errados para atingir fins aparentemente corretos. Nesse sentido, há uma relação proposital, criada intencionalmente por George Lucas, entre a queda de Anakin e a ascensão do Império Galáctico.

De acordo com a principal influência teórica de George Lucas, o estudioso norteamericano de mitologia e religião comparada Joseph Campbell (1904-1987), a narratologia apresentada na saga Star Wars não deve ser interpretada meramente como "uma história de moralidade", pois na perspectiva desse autor há uma outra perspectiva, que poderíamos denominar como "praxiológica", visto que "o filme tem a ver com os poderes da vida, conforme sejam plenamente realizados ou cerceados $e$ suprimidos pela ação do homem"17. Tal qual a já clássica formulação praxiológica de Ludwig von Mises:

Ação humana é comportamento propositado. Também podemos dizer: ação é a vontade posta em funcionamento, transformada em força motriz; é procurar alcançar fins e objetivos; é a significativa resposta do ego aos estímulos e às condições do seu meio ambiente; é o ajustamento consciente ao estado do universo que lhe determina a vida. Estas paráfrases podem esclarecer a definição dada e prevenir possíveis equívocos. Mas a própria definição é adequada e não necessita de complemento ou comentário ${ }^{18}$.

O exame acurado da tragédia apresentada pela narratologia da saga Star Wars deverá levar em consideração tanto os aspectos moralizantes da queda de Anakin Skywalker quanto o caráter praxeológico das escolhas propositadas tomadas por esta personagem diante das condições políticas

${ }^{17}$ CAMPBELL, Joseph \& MOYERS, Bill. O Poder do Mito. Org. Betty Sue Flowers; Trad. Carlos Felipe Moisés. São Paulo: Palas Athena, 1992. p. 154.

${ }^{18}$ MISES, Ludwig von. Ação Humana: Um Tratado de Economia. Trad. Donald Stewart Jr. São Paulo: Instituto Ludwig von Mises Brasil, 3ª Ed., 2010. p. 35. 
que se apresentaram, comportamentos estes que, como já ressaltado, estão intimamente ligados à ascensão do Império Galáctico. A postura de Anakin quando acredita nas promessas de Palpatine, segundo a qual a manutenção da estabilidade da ordem política externa dependeria necessariamente da ampliação dos poderes estatais, se assemelha ao que o filósofo Eric Voegelin (1901-1985), ao analisar a ascensão do nacional-socialismo, denominou de conflito entre a "primeira realidade" e a "segunda realidade", quando, diante da desordem social, os indivíduos tentam resolver a crise colocando uma pseudo-ordem no lugar da ordem real, substituindo a realidade por uma falsa imagem da realidade ${ }^{19}$.

Persistimos em advogar que o conceito de "Ordem" seja "talvez o mais importante dentre todos os abordados pela Filosofia Política"20. Nas palavras de F. A. Hayek a "ordem é um conceito indispensável ao exame de todos os fenômenos complexos", pois esta denota, basicamente, "o mesmo papel que o conceito de lei desempenha na análise de fenômenos mais simples" ${ }^{\prime 21}$. Ao passo que para Russell Kirk:

A ordem, no campo da moral, é a concretização de um corpo de normas transcendentes - de fato uma hierarquia de normas ou padrões-que conferem propósito à existência e motivam a conduta. A ordem, na sociedade, é o arranjo harmonioso de classes e funções que preservam a justiça, obtém o consentimento voluntário à lei e assegura que todos, juntos, estaremos a salvo. Embora não possa haver liberdade sem ordem, num certo sentido, há sempre

${ }^{19}$ VOEGELIN, Eric. Hitler e os Alemães. Intr. e Ed. Detlev Clemens e Brendan Purcell; Trad. Elpídio Mário Dantas Fonseca. São Paulo: É Realizações, 2007. p. 14348.

${ }^{20}$ CATHARINO. A Imaginação Moral em Star Wars. p. 248.

${ }^{21}$ HAYEK, F. A. Direito, Legislação e Liberdade: Uma Nova Formulação dos Princípios Liberais de Justiça e Economia Política - Volume I: Normas e Ordem. Apres. Henry Maksoud; Trad. Anna Maria Capovilla, José Ítalo Stelle, Manuel Paulo Ferreira e Maria Luiza X. de A. Borges. São Paulo: Visão, 1985. p. 35-36. um conflito entre os clamores da ordem e os da liberdade. Muitas vezes expressamos esse conflito como a competição entre o desejo de liberdade e o desejo de segurança ${ }^{22}$.

A concepção de Ordem, no modo como é entendida pelo conservadorismo de Russell Kirk, está intimamente conectada, por um lado, à tradição histórica da sociedade, o que permite alguns pontos de interseção entre esta e a percepção adotada pelo liberalismo de F. A. Hayek, que assume uma natureza sociológica e evolutiva. Na perspectiva hayekeana "é claro que toda sociedade deve possuir uma ordem, nesse sentido, e que tal ordem existirá sem ter sido intencionalmente criada"23. Conforme evidenciamos em outro ensaio ${ }^{24}$, tanto o "princípio da consagração pelo uso"25 quanto o entendimento de "Tradição" 26 defendidos pelo conservadorismo de Kirk guarda inúmeros aspectos similares com o conceito de "Ordem Espontânea" ou kóouos (kósmos), definido por Hayek como "uma ordem resultante da evolução", um tipo não criado de forma deliberada, mas "autogeradora ou endógena"27. No pensamento hayekano o conceito de "ordem espontânea" ou kóouos (kósmos) é contraposto à noção de "ordem feita" ou "ordenação" ou tákłıs (táxis), que é entendida "como uma construção, como uma

${ }^{22}$ KIRK, Russell. The Tension of Order and Freedom in the University. In: Redeeming the Time. Edited with an Introduction by Jeffrey O. Nelson. Wilmington: ISI Books, 1996. p. 33.

${ }^{23}$ HAYEK. Direito, Legislação e Liberdade. Vol. I, p. 36.

${ }^{24}$ CATHARINO, Alex. A Escola Austríaca entre a Tradição e a Inovação. MISES: Revista Interdisciplinar de Filosofia, Direito e Economia, Vol. I, No. 2 (jul.-dez. 2013): 305-23, Esp. 308-15.

${ }^{25}$ KIRK, Russell. Dez Princípios Conservadores. In: A Política da Prudência. Apres. Alex Catharino; Intr. Mark C. Henrie; Trad. Gustavo Santos e Márcia Xavier de Brito. São Paulo: É Realizações, 2013. p. 106.

${ }^{26}$ Idem. A Era de T. S. Eliot. p. 199-202, 373-74.

${ }^{27}$ HAYEK. Direito, Legislação e Liberdade. Vol. I, p. 38. 
ordem artificial" ou como "uma ordem social dirigida, como uma organização" 28 .

Por outro lado, a concepção kirkeana de Ordem ressalta a inter-relação entre a ordem social externa da comunidade e a ordem espiritual interna da pessoa, o que, em muitos aspectos, a aproxima da definição ontológica adotada por Eric Voegelin, segundo a qual "Ordem é a estrutura da realidade como experimentada pelo homem" e, ao mesmo tempo, "a sintonia entre o homeme uma ordem não fabricada por ele, isto é, a ordem cósmica"29. De acordo com a filosofia noética voegeliniana "a realidade não é um sistema", logo, quando "o sujeito constrói um sistema, a falsificação da realidade" se torna inevitável ${ }^{30}$. Devido ao fato da sociedade ser "iluminada por um complexo simbolismo, com vários graus de compactação e diferenciação", que é parte integrante da realidade, as análises da Ciência Política devem elaborar seus conceitos "a partir do rico conjunto de auto-representações da sociedade ${ }^{\prime 31}$. Com base nesses pressupostos teóricos Voegelin afirma que:

A sociedade política pode dissolver-se não apenas pela desintegração das crenças que fazem dela uma unidade atuante na história, mas também pode ser destruída pela dispersão de seus membros de tal maneira que a comunicação entre eles se torne fisicamente impossível ou, mais radicalmente, por sua eliminação física; pode igualmente, sofrer danos sérios, destruição parcial da tradição ou paralisia prolongada mediante o extremismo ou opressão dos membros ativos que constituem as minorias políticas e intelectuais que dirigem a sociedade $^{32}$.

\footnotetext{
${ }^{28}$ Idem. Ibidem., Vol. I, p. 38.

${ }^{29}$ VOEGELIN, Eric. Reflexões Autobiográficas. Intr. e ed. Ellis Sandoz; Trad. Maria Inês de Carvalho; Notas de Martim Vasques da Cunha. São Paulo: É Realizações, 2007. p. 117.

${ }^{30}$ Idem. Ibidem. p. 119.

${ }^{31}$ VOEGELIN, Eric. A Nova Ciência da Política. Apres. José Pedro Galvão de Sousa; Trad. José Viegas Filho. Brasília: Editora Universidade de Brasília, 2ª Ed., 1982. p. 33.

${ }^{32}$ Idem. Ibidem. pp. 35-36.
}

No caso específico da saga Star Wars, é possível afirmar que os maiores problemas da República Galáctica eram a falta de entendimento entre os representantes dos diferentes sistemas planetários ou corporações e a corrupção dos políticos e burocratas. Entretanto, havia, nesse regime democrático, com todos os defeitos, a possibilidade do livre debate em busca de entendimento político. A partir de uma crise gerada pela criação de novos tributos sobre rotas comerciais e com a promessa falaciosa de solucionar os problemas da sociedade, em um primeiro momento, o Senador Palpatine foi eleito Chanceler Supremo com o compromisso de acabar com a corrupção na República ${ }^{33}$. Em um segundo momento, com a eclosão dos movimentos separatistas e o início de uma guerra de secessão $0^{34}$, o aparente empenho do Chanceler Supremo Palpatine foi a restauração da paz e da justiça, cujo resultado foi a criação de uma nova ordem política autoritária e militarizada, com a pacificação ocorrendo apenas pela submissão de toda a sociedade à vontade arbitrária do governante e pela eliminação de qualquer possibilidade de oposição ao regime ${ }^{35}$, o que acabou gerando um novo conflito. Acreditando que o poder poderia ser mantido pelo medo da Estrela da Morte, uma estação de batalha capaz de destruir um planeta por completo, o Imperador Palpatine dissolveu o Senado,

\footnotetext{
${ }^{33}$ Ver o filme Star Wars: Episódio I - A Ameaça Fantasma. Ver, também, o livro: BROOKS, Terry. Star Wars: Episode I - The Phantom Menace. Based on the screenplay and story by George Lucas. New York: Ballantine Books, 1999.

${ }^{34}$ Ver o filme Star Wars: Episódio II - Ataque dos Clones. Ver, também, o livro: SALVATORE, S. A. Star Wars: Episode II - Attack of the Clones. Based on the story and screenplay by George Lucas. New York: Ballantine Books, 2002.

${ }^{35}$ Ver o filme Star Wars: Episódio III - A Vingança dos Sith. Ver, também, o livro: STOVER, Matthew. Star Wars: Episode III - Revenge of the Sith. (Based on the screenplay and story by George Lucas). New York: Ballantine Books, 2005.
} 
último resquício da antiga ordem ${ }^{36}$, e planejou destruir a Aliança Rebelde, principal foco de resistência ao seu regime ditatorial ${ }^{37}$. Mas, toda a luta política dos rebeldes só teve um desfecho positivo, com uma vitória militar contra o Império Galáctico que pode ser um meio externo de restaurar a correta ordem da sociedade, porque a ordem interna da alma de Anakin Skywalker foi restaurada. Como nos lembra Russell Kirk:

Uma existência desordenada é uma existência confusa e miserável. Se a sociedade recair numa desordem geral, muitos de seus membros deixarão de existir. E, se os membros de uma sociedade são desordenados em espírito, a ordem exterior da comunidade não pode perdurar ${ }^{38}$.

A temática da Ordem ocupou espaço significativo no editorial que elaboramos em 2013 para a segunda edição da MISES: Revista Interdisciplinar de Filosofia, Direito e Economia ${ }^{39}$, bem como em nosso artigo, já citado, sobre Star Wars publicado em 2009 na COMMUNIO: Revista Internacional de Teologia e Culturato, motivo pelo qual não nos deteremos mais neste assunto no presente ensaio. Na próxima seção de nosso trabalho pretendemos aprofundar as reflexões acerca da Filosofia

\footnotetext{
36 Ver o filme Star Wars: Episódio IV - Uma Nova Esperança. Ver, também, o livro: LUCAS, George. Star Wars: Episode IV - A New Hope. New York: Ballantine Books, 1976.

${ }^{37}$ Ver os filmes Star Wars: Episódio V-O Império ContraAtaca e Star Wars: Episódio VI - O Retorno de Jedi. Ver, também, os livros: GLUT, Donald F. Star Wars: Episode V - The Empire Strikes Back. Based on the story by George Lucas and the screenplay by Leigh Brackett and Lawrence Kasdan. New York: Ballantine Books, 1980; KAHN, James. Star Wars: Episode VI - Return of Jedi. Based on the story by George Lucas and the screenplay by Lawrence Kasdan and George Lucas. New York: Ballantine Books, 1983.
}

38 KIRK, Russell. The Roots of American Order. Edited with a New Foreword by Forrest McDonald. Wilmington: ISI Books, $4^{\text {th }}$ Ed., 2003. p. 5.

${ }^{39}$ CATHARINO. A Escola Austríaca entre a Tradição e a Inovação. p. 305-23.

${ }^{40}$ Idem. A Imaginação Moral em Star Wars. p. 248-50.
Moral e da Teoria Política que perpassam a narratologia da saga Star War, destacando o modo como tal alegoria pode ser apropriada como instrumento pedagógico para esclarecer alguns postulados teóricos defendidos pela Escola Austríaca, em particular a concepção de Liberdade Individual advogada nos escritos de Ludwig von Mises, F. A. Hayek e Murray N. Rothbard, que foram explicitadas de modo mais amplo no início da primeira parte do nosso ensaio ${ }^{41}$.

\section{IV - A Filosofia Moral e Teoria Política de STAR WARS}

Tanto na trilogia mais antiga da saga Star Wars, formada pelos episódios IV, V e VI, quanto na trilogia mais recente, composta pelos episódios I, II e III, os temas políticos fornecem um importante cenário para o desenvolvimento das aventuras. A nova trilogia, no entanto, apresenta uma trama mais complexa para nosso propósito de analisar a Teoria Política, bem como algumas questões econômicas, que perpassam a narratologia das estórias.

Ao criar Star Wars George Lucas se questionou sobre a maneira "como as democracias se tornam ditaduras", não na perspectiva de como são derrubadas por golpes, "mas como a democracia se empresta a um tirano". Para compor esse pano de fundo político o cineasta norte-americano afirmou ter estudado o problema ao decorrer do processo histórico, buscando entender como o Senado Romano, após assassinar Júlio César (100-44 a.C.), entregou o poder para Otávio Augusto (63 a.C.-14 A.D.) ou como na Revolução Francesa, após a decapitação de Luís XVI (1754-1793), Napoleão Bonaparte (1769-1821) se coroou imperador dos franceses, bem como a maneira que, diante da tibieza da presidência de Paul von Hindenburg (1847-1934), o líder

${ }^{41}$ Idem. A Filosofia da Liberdade na Saga de Filmes Star Wars - Parte 1. p. 262-65. 
nazista Adolf Hitler (1889-1945) foi alçado democraticamente ao cargo de Chanceler da Alemanha. Na percepção de George Lucas os riscos de uma democracia entregar os poderes a um tirano "acontece muito mais do que se imagina", "tem mais a ver com o precedente histórico". Dando continuidade aos seus comentários ele afirmou que:

Geralmente, você imagina que um grupo assume o poder. [...] Mas o processo é mais interessante quando o governo é entregue para compensar o fato dos representantes eleitos não concordarem em nada e serem corruptos. Portanto, para limpar a bagunça, alguém precisa chegar e consertar tudo ${ }^{42}$.

No Episódio I: A Ameaça Fantasma descobrimos que o início da crise política por detrás do conflito militar que serviu como meio para o Senador Palpatine assumir o cargo se Chanceler Supremo da República foi originada pela criação de novos tributos sobre o comércio. Nos créditos iniciais do filme, isto é anunciado com as seguintes palavras:

A República Galáctica está em grande tumulto. Em disputa estão os impostos sobre as rotas comerciais para os sistemas estelares exteriores.

$\mathrm{Na}$ esperança de resolver o assunto com um bloqueio de implacáveis naves de guerra, a ávida Federação de Comércio interrompe todos os carregamentos para o pequeno planeta Naboo. $[\ldots]^{43}$.

Os seis filmes da saga não oferecem maiores detalhes sobre o funcionamento do regime político ou do sistema econômico da República Galáctica. Por intermédio de algumas passagens tanto no Episódio I: A Ameaça Fantasma quanto no Episódio II: O Ataque dos Clones é possível inferir que o modelo democrático adotado era extremamente corrupto devido ao excessivo grau de burocratização das instituições civis.

\footnotetext{
${ }^{42}$ Declarações feitas nos comentários de áudio ao filme Star Wars: Episódio III - A Vingança dos Sith.

${ }^{43}$ Star Wars: Episódio I - A Ameaça Fantasma. A partir de 0:00:50.
}

De modo semelhante é factível depreender que no plano econômica o modelo da República Galáctica se assemelha ao chamado capitalismo clientelista ou capitalismo de compadrio (Crony Capitalism), um sistema extremamente regulamentado pela esfera estatal e controlado por diferentes corporações como a Federação de Comércio, a Associação Comercial, a Aliança Corporativa, a União Tecnológica e o Clã Bancário, dentre outras, cujas franquias operacionais eram concedidas pelo Senado.

O capitalismo clientelista ou capitalismo de compadrio é um sistema econômico intervencionista no qual o sucesso financeiro dos negócios depende das estreitas relações pessoais ou corporativas entre os empresários e os funcionários da burocracia estatal. Tal modelo foi definido por Ludwig von Mises nos respectivos termos:

$\mathrm{O}$ intervencionismo procura manter a propriedade privada dos meios de produção. No entanto, ordens autoritárias, especialmente proibições, restringem as ações dos proprietários. Se essas restrições fizerem com que todas as decisões importantes sejam tomadas de forma autoritária, se o motivo não é o lucro dos proprietários, capitalistas e empresários, mas razões de Estado, o que vai decidir como e o que deve ser produzido, teremos, então, o socialismo, mesmo que se continue a empregar a expressão "propriedade privada". Othmar Spann (1878-1950) está inteiramente certo quando diz que tal sistema é "um sistema de propriedade privada em sentido formal, mas socialismo na sua essência". A propriedade pública dos meios de produção nada mais é do que socialismo, ou comunismo.

Entretanto, o intervencionismo não pretende ir tão longe. Não procura eliminar a propriedade privada da produção, mas apenas limitá-la. Por um lado, considera a propriedade privada ilimitada prejudicial à sociedade, e, por outro, considera que uma ordem baseada apenas na propriedade pública não é totalmente viável, pelo menos por enquanto. Procura, portanto, criar uma terceira ordem: um sistema 
social intermediário entre a propriedade privada e a propriedade pública. Desta forma, procura evitar os "excessos" e males do capitalismo, mantendo, contudo, as vantagens da iniciativa e indústria privadas, que o socialismo não pode gerar ${ }^{44}$.

Na saga Star Wars um quadro parcial tanto da endêmica corrupção nas instituições quanto da situação de desentendimento político criadas pelo excesso de intervenção governamental e pelo elevado controle burocrático é fornecido pelo seguinte diálogo entre o astuto Senador Palpatine e a ingênua Rainha Amidala, respectivamente, o representante e a soberana de Naboo:

[Palpatine]: Não há nenhuma civilidade, apenas política. A República não é mais o que era antes. O Senado só tem representantes gananciosos e briguentos. Não há o menor interesse no bem-comum. Para ser franco o Senado não atuará contra a invasão.

[Amidala]: O Chanceler Valorum acha que há esperança.

[Palpatine]: Se me permite dizer, o Chanceler tem pouco poder real. Está minado por acusações infundadas de corrupção. Os burocratas comandam.

[Amidala]: Quais são as opções?

[Palpatine]: Primeiro, forçar a eleição de um Chanceler Supremo mais forte. Uma pessoa que possa controlar os burocratas e fazer justiça. A Rainha poderia questionar a posição do Chanceler Valorum...

44 MISES, Ludwig von. Uma Crítica ao Intervencionismo. Intr. Hans F. Sennholz; Trad. Arlette Franco. São Paulo: Instituto Ludwig von Mises Brasil, 2010. p. 17-18. Para uma descrição sintética acerca da temática, ver: BARBIERI, Fabio. A Teoria Austríaca do Intervencionismo. MISES: Revista Interdisciplinar de Filosofia, Direito e Economia, Vol. I, No. 1 (jan.-jun. 2013): 75-86. Na maioria dos casos, a adoção do intervencionismo como modelo econômico é justificada pela crença falaciosa de este é um meio efetivo de eliminar as pretensas "falhas de mercado", que na verdade são criadas pela interferência estatal no processo de mercado, tal como demonstrado em: IORIO, Ubiratan Jorge. A Grande Ficção das Falhas de Mercado. MISES: Revista Interdisciplinar de Filosofia, Direito e Economia, Vol. I, No. 2 (jul.-dez. 2013): 401-24.
[Amidala]: Ele tem sido o nosso principal apoiador.

[Palpatine]: A nossa outra opção seria submeter um pedido ao Tribunal...

[Amidala]: As cortes demoram mais a resolver as coisas que o Senado. Nosso povo está morrendo Senador. Devemos agir rápido para deter a Federação.

[Palpatine]: Para ser realista, Majestade, temos que aceitar o controle da Federação, por enquanto.

[Amidala]: Isso é algo que não posso fazer ${ }^{45}$.

A essência do mesmo problema foi relatada no episódio II nas seguintes advertências de Obi-Wan Kenobi para Anakin Skywalker:

Políticos não são confiáveis. Os senadores só ligam para os que financiam suas campanhas, esquecem as suas sutilezas da democracia para obter dinheiro. [...]

Palpatine é um político. Ele é esperto o bastante para acompanhar as paixões e preconceitos dos senadores ${ }^{46}$.

Quando o ainda Senador Palpatine e a Rainha Amidala expuseram para o Senado a situação dramática do Planeta Naboo, vítima de um bloqueio de naves e, posteriormente, invadido por um exército de androide de batalha da Federação de Comércio, foi iniciado um caloroso debate, cuja resolução do Chanceler Supremo Valorum, por intermédio da proposta de um burocrata, foi a criação de um comitê de inquérito com o objetivo de estudar a disputa comercial e a legalidade da intervenção militar. Manipulando a soberana de Naboo para que esta propusesse um "Voto de Desconfiança" acerca da liderança de Valorum, possibilitando que novas eleições fossem convocadas, o ambicioso Palpatine explica a movimentação política no Senado da República Galáctica sussurrando para Amidala as seguintes palavras: "eis que surge o

\footnotetext{
${ }^{45}$ Star Wars: Episódio I - A Ameaça Fantasma. A partir de $1: 22: 45$.

${ }^{46}$ Star Wars: Episódio II - O Ataque dos Clones. A partir de 0:12:40.
} 
burocrata, eles dominam a Repúblicae estão na folha de pagamento da Federação Comercial, e é aí que a força do Chanceler Valorum vai desaparecer" ${ }^{\prime \prime}$. Em consequência desta advertência a rainha de Naboo contestou a liderança de Valorum, o que levou a destituição deste do cargo de Chanceler Supremo pelo Senado, e fez Palpatine afirmar com júbilo: "agora vão eleger um novo Chanceler, alguém que seja forte"48. Dentre os três possíveis sucessores de Valorum, surgiu o nome de Palpatine, que tomou o seguinte compromisso de campanha: "se for eleito, prometo acabar com a corrupção" 49 . Após ter sido eleito Chanceler Supremo, Palpatine prometeu à Rainha Amidala e aos membros da ordem dos Cavaleiro Jedi mudanças políticas com as respectivas palavras: "juntos levaremos paz e prosperidade à República"

Cerca de dez anos depois dos eventos do episódio I, se desenvolveu os acontecimentos do segundo filme, cujos créditos iniciais delineiam o contexto que se desenvolverá a trama com as seguintes palavras:

Há apreensão no Senado Galáctico. Milhares de sistemas solares manifestaram sua intenção de deixar a República.

Esse movimento separatista, sob a liderança do misterioso Conde Dookan, tornou difícil para o pequeno número de Cavaleiros Jedi manter a paz e a ordem na Galáxia.

A Senadora Amidala, ex-rainha de Naboo, está voltando ao Senado Galáctico para votar a delicada questão de criar um Exército da República para ajudar os combalidos Jedi ${ }^{51}$.

Em uma reunião com os mestres do conselho da Ordem dos Cavaleiros Jedi, após ter ocorrido um atentado terrorista

47 Star Wars: Episódio I - A Ameaça Fantasma. A partir de 1:28:10.

48 Star Wars: Episódio I - A Ameaça Fantasma. A partir de 1:29:00.

49 Star Wars: Episódio I - A Ameaça Fantasma. A partir de 1:31:15.

${ }^{50}$ Star Wars: Episódio I - A Ameaça Fantasma. A partir de 2:06:13.

${ }^{51}$ Star Wars: Episódio II - O Ataque dos Clones. A partir de 0:00:50. objetivando tirar a vida da Senadora Padmé Amidala, o Chanceler Supremo Palpatine apresenta o firme propósito de não sucumbir às forças de secessão com as seguintes palavras: "não deixarei essa República que existe há mil anos rachar-se em duas" maioria dos autores libertários ${ }^{53}$ e com uma parcela significativa de notórios pensadores conservadores ${ }^{54}$, tendemos, por uma questão

52 Star Wars: Episódio II - O Ataque dos Clones. A partir de 0:04:30.

53 O direito de secessão foi defendido por vários pensadores associados à Escola Austríaca, dentre os quais se destacam Ludwig von Mises, F. A. Hayek, Murray N. Rothbard, Hans-Hermann Hoppe, Thomas J. DiLorenzo e Donald W. Livingston. Para uma análise sintética da temática da secessão no pensamento austríaco, consultar: SILVA, Daniela Sofia Gomes da \& ALVES, André Azevedo. Secessão e Federalismo na Perspectiva da Escola Austríaca. MISES: Revista Interdisciplinar de Filosofia, Direito e Economia, Vol. I, No. 2 (jul.-dez. 2013): 589-601. Uma excelente seleção de ensaios sobre o assunto, com diversas indicações bibliográficas, se encontra em: GORDON, David (Ed.). Secession, State and Liberty. New Brunswick: Transactions Publishers, 1998. Ver, também: McGEE, Robert W. Secession Reconsidered. The Journal of Libertarian Studies, Vol. 11, No. 1 (Fall 1994): 11-33; LIVINGSTON, Donald. The Very Idea of Secession. Society, Vol. 35, No. 5 (July-August 1998): 38-48; KREPTUL, Andrei. The Constitutional Right of Secession in Political Theory and History. The Journal of Libertarian Studies, Vol. 17, No. 4 (Fall 2003): 39100; LIVINGSTON, Donald (Ed.). Rethinking the American Union for the Twenty-First Century. Gretna: Pelican Publishing Company, 2012.

54 Uma das possíveis matrizes conservadoras para a advocacia do direito de secessão se encontra no pensamento político do filósofo jusnaturalista e teólogo calvinista alemão Johannes Althusius (15631638), cuja principal obra, lançada originalmente em 1614, foi publicada em português na seguinte edição brasileira: ALTHUSIUS, Johannes. Política. Ed. e intr. Frederick S. Carney; Pref. Daniel J. Elazar; Trad. Joubert de Oliveira Brízida. Rio de Janeiro: Topbooks, 2003. As ideias deste pensador alemão influenciaram os ideais antifederalistas e secessionistas de inúmeros autores norte-americanos, dentre os quais se destacam os sulistas John Randolph (1773-1833) de Roanoke e John C. Calhoun (1782-1850), que são importantes referências para o conservadorismo de Russell Kirk, tal como apresentado, especialmente, em: KIRK, Russell. The Conservative Mind: From Burke to Eliot. Intr. 
de princípios teóricos, a simpatizar com a causa separatista, por acreditar que esta é, provavelmente, o mais efetivo instrumento de limitação dos poderes estatais e de ampliação da liberdade individual. Todavia, a adesão aos princípios conservadores da "consagração pelo uso", da "prudência" e da "imperfectibilidade", tal como apresentados pelo pensamento kirkeano ${ }^{55}$, não permite que aceitemos nortear a ação política meramente por ideias abstratas, sem levar em consideração os limites do conhecimento humano, as circunstâncias reais e as possíveis consequências de longo prazo das ações concretas.

No caso específico da saga Star Wars, devemos lembrar que tanto a autoridade política da República Galáctica quanto o Exército Droide Separatista eram controlados, por diferentes meios, pelo ambicioso Chanceler Supremo Palpatine, o manipulador Darth Sidious, visto que o aparente líder dos sistemas que lutavam pela secessão era o Conde Dookan, que, na verdade, era Darth Tyranus, um discípulo secreto do maléfico lorde Sith. Outro fator que deve ser levado em consideração é o fato dos separatistas na série não serem defensores da liberdade, pois eram controlados por um conselho de representantes de diferentes corporações e, ao mesmo tempo, detentores de uma opressora força militar. As palavras de Jar Jar Binks na

Henry Regnery. Washington D.C., Regnery Publishing, $7^{\text {th }}$ Ed. rev., 1986. p. 150-84. Sobre o pensamento de John Randolph de Roanoke, consultar: KIRK, Russell. John Randolph of Roanoke: A Study in American Politics - With Selected Speechs and Letters. Indianapolis: Liberty Fund, $4^{\text {th }}$ Ed., 1997. Os principais escritos de John. C. Calhoun estão disponíveis nas seguintes edições: CALHOUN, John C. A Disquisition on Government. Ed. H. Lee Cheek Jr. South Bend: St. Augustines Press, 2007; Idem. A Discourse on the Constitution and Government of the United States. Gloucester: Dodo Press, 2008. A relevância dos escritos deste autor é ressaltada em: KIRK, Russell. Calhoun Vindicated: Reflections on the Message of Calhoun for the 1980's. The Southern Partisan, Vol. 3, no. 1 (Winter 1983): 10-11.

${ }^{55}$ KIRK. Dez Princípios Conservadores. In: A Política da Prudência. p. 106-08. audiência no Senado que propôs a ampliação dos poderes do Chanceler Supremo Palpatine demonstram a maneira como o movimento separatista, por intermédio da aliança com a Federação de Comércio, foi um pretexto para, democraticamente, o poder discricionário ser alargado em detrimento da liberdade. Eis o diálogo da sequência cinematográfica:

[JarJar]: Está claro que os separatistas fizeram um pacto com a Federação de Comércio. Senadores, amigos delegados, em resposta a essa ameaça direta à República, proponho que o Senado dê imediatamente poderes de emergência ao Chanceler Supremo.

[Todos os senadores gritam]: PALPATINE! PALPATINE! PALPATINE!

[Palpatine]: É com grande relutância que eu concordo com esta convocação. Eu amo a democracia. Eu amo a República. Do poder que me deram eu abdicarei quando esta crise for controlada.

(Aplausos efusivos de todos os senadores) [Palpatine]: E como o meu primeiro ato com esse novo poder, criarei um exército da República para conter as crescentes ameaças dos separatistas ${ }^{56}$.

Contudo, a eclosão das Guerras Clônicas, travada entre o exército de clones da República liderado pelos cavaleiros Jedi e o exército de androides dos separatistas da Confederação de Sistemas Independentes comandados pelo Conde Dookan e pelo General Grievous, foi um elemento tanto para o enfraquecimento das instituições políticas quanto para a gradativa ampliação dos poderes discricionários do Supremo Chanceler Palpatine. Os créditos iniciais do Episódio III: A Vingança dos Sith, apresentam esse contexto com a respectiva sentença:

Guerra! A República está desmoronando sob o ataque do impiedoso Conde Dookan. Há heróis de ambos os lados. O mal está por toda parte. $[\ldots]^{57}$.

\footnotetext{
${ }^{56}$ Star Wars: Episódio II - O Ataque dos Clones. A partir de 1:33:45.

${ }^{57}$ Star Wars: Episódio III - A Vingança dos Sith. A partir de 0:00:50.
} 
No final do episódio II, conforme ressaltou com desapontamento o Mestre Yoda para Obi-Wan Kenobi: "Não houve vitória! O manto do Lado Negro caiu. As Guerras Clônicas começaram ${ }^{\prime \prime 5}$. O principal resultado deste conflito militar na esfera política, mesmo entre os mais fiéis defensores do governo constituído, foi o surgimento de uma crescente desconfiança em relação aos caminhos tomados pelas autoridades estatais, o que foi o germe da futura Aliança Rebelde, que se tornou o principal foco de resistência ao Império Galáctico nos episódios IV: Uma Nova Esperança, V: O Império Contra-Ataca, e VI: Retorno de Jedi. O descontentamento inicial com a República Galáctica pode ser ilustrado pelas palavras da Senadora Padmé Amidala no seguinte diálogo com Anakin Skywalker:

[Anakin]: As vezes, me questiono sobre o que está acontecendo com a Ordem dos Jedi. Está guerra está destruindo os princípios da República.

[Padmé]: Você já considerou que podemos estar do lado errado?

[Anakin]: o que quer dizer?

[Padmé]: $E$ se a democracia que imaginamos servir não existe mais? Se a República se tornou o mal que devemos combater e destruir?

[Anakin]: Não acredito nisso. Você está parecendo uma separatista.

[Padmé]: Essa guerra é um fracasso a ser analisado. Vocêé muito ligado ao Chanceler. Por favor, solicite o fim da luta e a volta da diplomacia.

[Anakin]: Não me peça para fazer isso. Apresente uma moção no Senado que é o lugar disso ${ }^{59}$.

Já no episódio I é possível verificar o início da ligação de Palpatine com Anakin Skywalker, quando o astuto político se dirigiu para o jovem Padawan e afirmou:

\footnotetext{
${ }^{58}$ Star Wars: Episódio II - O Ataque dos Clones. A partir de 2:13:40.

${ }^{59}$ Star Wars: Episódio III - A Vingança dos Sith. A partir de 0:41:21.
}

"Acompanharemos sua carreira com interesse" Após mais de uma década transcorrida, no episódio III, a contínua ligação entre os dois fica explicita na seguinte conversa entre ObiWan Kenobi e Anakin, quando o primeiro solicita que o segundo investigue Palpatine e relate suas ações suspeitas ao Conselho Jedi:

[Anakin]: O Chanceler não é um homem mau, Obi-Wan. Ele fez amizade comigo. Cuidou de mim. Desde que cheguei aqui.

[Obi-Wan]: Por isso tem que nos ajudar. Devemos lealdade ao Senado, não ao seu líder, que tratou de ficar no cargo depois que o mandato expirou.

[Anakin]: O Senado pediu para ele ficar.

[Obi-Wan]: Use sua percepção. Tem alguma coisa errada.

[Anakin]: Está me pedindo para violar o Código Jedi. Trair a República, um mentor e amigo. Isso é o que está errado. Por que você me pede isso?

[Obi-Wan]: É o Conselho que está pedindo ${ }^{61}$.

A incapacidade de Anakin diferenciar a lealdade às instituições políticas da fidelidade ao governante, bem como a ingênua crença nas promessas de Palpatine, é resultante do já citado fenômeno que o filósofo Eric Voegelin definiu como o conflito entre a "primeira realidade" e a "segunda realidade" 62 . No episódio II, a temerária ideia de instauração do governo de um líder messiânico fica explicita no seguinte diálogo entre a Padmé e Anakin, no qual o último expressa a visão política autoritária de Palpatine:

[Padmé]: Vocênão gosta mesmo de políticos! [Anakin]: Gosto de dois ou três. Mas não estou certo sobre um deles. Não acho que o sistema funcione!

[Padmé]: Como você o faria funcionar?

[Anakin]: Os políticos deveriam sentar, discutir o problema, concluir o que é melhor para o povo, e agir.

\footnotetext{
${ }^{60}$ Star Wars: Episódio I - A Ameaça Fantasma. A partir de 2:00:49.

${ }^{61}$ Star Wars: Episódio III - A Vingança dos Sith. A partir de 0:39:38.
}

${ }^{62}$ VOEGELIN. Hitler e os Alemães. p. 143-48. 
[Padmé]: É o que fazemos! Mas nem sempre as pessoas estão de acordo.

[Anakin]: Então, deviam ser convencidas.

[Padmé]: Por quem?

[Anakin]: Não sei! Alguém.

[Padmé]: Você?

[Anakin]: Claro que não!

[Padmé]: Quem, então?

[Anakin]: Alguém sábio.

[Padmé]: Está me soando como uma ditadura.

[Anakin]: Bem... se é o que funciona...63

No episódio III, ao conversar com ObiWan, mais uma vez Anakin defende a ideia errônea segundo a qual a concentração do poder político representaria uma melhoria na atuação governamental, utilizando as seguintes palavras:

[Anakin]: Qual o problema então?

[Obi-Wan]: O Senado deve votar hoje uma ampliação dos poderes executivos do Chanceler.

[Anakin]: Vai significar menos burocracia e mais ação. Isso é ruim? Será mais fácil acabar com essa guerra.

[Obi-Wan]: Tenha cuidado com seu amigo Palpatine.

[Anakin]: Cuidado com o que?

[Obi-Wan]: Ele requisitou sua presença ${ }^{64}$.

Os regimes ditatoriais extremamente centralizados e intervencionistas, diante de um contexto de desordem social, tendem a ser vistos como a solução para todas as mazelas criadas pelas falhas do processo de decisões políticas, quando, na verdade, não passas da instauração de uma pseudo-ordem no lugar da ordem real, que, em última instância é uma neurótica substituição da realidade por uma falsa imagem desta. Ludwig von Mises explica os fundamentos psicológicos da tal popularidade exercita pelas ditaduras do seguinte modo:

A sociedade não é o que o indivíduo gostaria que fosse. [...] O neurótico tenta se

\footnotetext{
${ }^{63}$ Star Wars: Episódio II - Ataque dos Clones. A partir de 0:48:25.

${ }^{64}$ Star Wars: Episódio III - A Vingança dos Sith. A partir de 0:35:05.
}

proteger desses desapontamentos sonhando acordado. Sonha com um mundo no qual sua vontade seja decisiva. [...] Na sua fantasia, é um ditador. [...] $\mathrm{Na}$ vida real, quando fala com os seus conterrâneos, tem que ser mais modesto. Contenta-se em apoiar a ditadura de alguma outra pessoa. [...] Quem apoia uma ditadura, o faz por achar que o ditador está fazendo o que, na sua opinião, precisa ser feito. Quem é favorável a ditaduras tem sempre em mente a necessidade de dominar todas as vontades, inclusive a sua própria vontade $^{65}$.

Anakin cada vez menos seguia os conselhos de seu amigo Obi-Wan e, ao mesmo tempo, se deixava seduzir por Palpatine. Uma das artimanhas do malicioso lorde Sith foi criar a desconfiança em Anakin, fazendo-o acreditar que os Jedi, já pressentindo as verdadeiras intenções dele, queriam assumir o poder político e que ele era o único defensor do regime democrático. Tal processo fica evidente no seguinte diálogo entre os dois:

[Palpatine]: Anakin, você sabe que não posso contar com o Conselho Jedi. Se não incluíram você na trama deles, logo o farão. [Anakin]: Eu não entendo!

[Palpatine]: Já deve ter percebido quais são as minhas suspeitas. O Conselho Jedi quer assumir o controle da República. Eles estão planejando me trair.

[Anakin]: Não acredito que...

[Palpatine]: Anakin use sua percepção! Você sabe, não é?

[Anakin]: Sei que eles não confiam em você. [Palpatine]: Ou no Senado. Ou na República. Ou na democracia, melhor dizendo.

[Anakin]: Devo admitir que minha confiança neles está meio abalada.

[Palpatine]: Por quê? Pediram algo que o deixou constrangido, não foi? Queriam que me espionasse, certo?

[Anakin]: Eu não... não sei o que dizer.

[Palpatine]: Tente se lembrar de meus primeiros ensinamentos para você: todos

65 MISES, Ludwig von. Intervencionismo: Uma Análise Econômica. Ed. Bettina Bien Greaves; Trad. e comentários de Donald Stewart Jr. São Paulo: Instituto Ludwig von Mises Brasil, 2010. p. 110. 
que adquirem o poder têm medo de perdêlo. Até mesmo um Jedi ${ }^{66}$.

O relacionamento entre Palpatine e Anakin se assemelha ao de Mefistófeles e Fausto, onde o primeiro, num pacto satânico, corrompe o segundo ${ }^{67}$. Palpatine é o arquétipo do tentador, que seduz Anakin ao lhe oferecer os poderes para salvar a esposa da morte e, ao mesmo tempo, restaurar a ordem na sociedade, que se encontra assolada pela corrupção e pela guerra entre o exército de clones da República e o exército de androides dos separatistas. Após sucumbir a tentação de Palpatine, passar para o Lado Negro da Força, se transformar em Darth Vader, assassinar junto com uma divisão de soldados clones todos no Templo Jedi e ser encarregado por seu novo mestre de eliminar os líderes separatistas, ele se encontra com Padmé, antes de cumprir a última missão, e tenta justificar seus atos no seguinte diálogo:

[Padmé]: O que está havendo?

[Vader]: Os Jedi tentaram derrubar a República.

[Padmé]: Não posso acreditar nisso!

[Vader]: Vi o Mestre Windu tentar assassinar o Chanceler.

[Padmé]: Anakin, o que você vai fazer?

[Vader]: Não vou trair a República. Sou leal ao Chanceler. E ao Senado. E a vocêt $\hat{A}^{68}$.

George Lucas explica esse diálogo entre Vader e Padmé da seguinte forma:

\footnotetext{
${ }^{66}$ Star Wars: Episódio III - A Vingança dos Sith. A partir de 0:44:00.

67 Dentre as inúmeras narrativas sobre Fausto e Mefistófeles destacamos a peça teatral de Christopher Marlowe (1563-1593) e o romance de Johann Wolfgang von Goethe (1749-1832), que podem ser encontrados, respectivamente, nas seguintes edições: MARLOWE, Christopher. A História Trágica do Doutor Fausto. Intr. Dirceu Villa; Trad. e notas de A. de Oliveira Cabral. São Paulo: Hedra, 2006; GOETHE, Johann Wofgang von. Fausto: Uma Tragédia. Edição bilíngue traduzida por Jenny Klabin Segall. São Paulo: Editora 34, 2004 / 2007. 2v.

68 Star Wars: Episódio III - A Vingança dos Sith. A partir de 1:27:56.
}

Ninguém que é mau pensa em si mesmo assim. Sempre acha que está fazendo o bem, mesmo que não esteja. Então é uma questão de como uma pessoa boa acaba se tornando má ${ }^{69}$.

A importância do livre arbítrio no processo de aceitar o que é correto ou tentar manipular a realidade, como características distintivas entre o bem e o mal nas narrativas do gênero mitopoético já foi ressaltada em outro ensaio ${ }^{70}$, bem como mencionada na primeira parte desse estudo ${ }^{71}$, o que nos permite não aprofundar mais nossas reflexões sobre essa temática. Outra questão moral importante apresentada em Star Wars é que, tanto no plano pessoal quanto na esfera política, aquele que opta pelo caminho errado, busca, para se justificar, corromper, também, outras pessoas. Verificamos isso no seguinte diálogo:

[Vader]: O que você está fazendo aqui?

[Padmé]: Estava preocupada com você. Obi-Wan me contou coisas terríveis.

[Vader]: Que coisas?

[Padmé]: Disse que você passou para o Lado Negro. Que você... matou crianças.

[Vader]: Ele quer fazer você se voltar contra mim.

[Padmé]: Ele se importa conosco.

[Vader]: Conosco?

[Padmé]: Ele sabe. Quer ajudar você. Anakin, tudo que eu quero é o seu amor. [Vader]: O amor não salvará você. Só meus novos poderes podem fazer isso.

[Padmé]: A que preço? Você é uma pessoa boa. Não faça isso!

[Vader]: Não vou perder você como perdi a minha mãe. Estou me tornando mais poderoso do que qualquer Jedi já sonhou. Faço isso para proteger você.

${ }^{69}$ Declarações feitas no documentário The Chosen One [O Escolhido], de 2005, dirigido por Tippy Bushkin, que aparece como um dos extras do segundo disco da edição de DVD dupla do filme Episódio III: A Vingança dos Sith.

${ }^{70}$ CATHARINO. A Imaginação Moral em Star Wars. p. 228, 242.

${ }^{71}$ Idem. A Filosofia da Liberdade na Saga de Filmes Star Wars - Parte 1. p. 263, 268. 
[Padmé]: Venha embora comigo. Ajudeme a criar nosso filho. Deixe tudo para trás enquanto pode.

[Vader]: Você não me entende? Nós não temos mais que fugir. Eu trouxe a paz para a República. Tenho mais poder que o Chanceler. Eu posso derrubá-lo e nós dois juntos podemos governar a Galáxia! Fazer as coisas como queremos que sejam!

[Padmé]: Não acredito no que estou ouvindo. Obi-Wan tinha razão. Você mudou.

[Vader]: Não quero ouvir falar de ObiWan. Os Jedi se voltaram contra mim. Não faça o mesmo.

[Padmé]: Não reconheço mais você. Anakin, você está partindo meu coração. Está indo por um caminho que não posso trilhar.

[Vader]: Por causa de Obi-Wan?

[Padmé]: Por causa do que você fez. O que planeja fazer. Pare agora. Volte a ser quem era! Eu amo você.

[Vader]: Mentirosa! ${ }^{72}$.

Obstinamo-nos em sustentar que as duas trilogias de filmes Star Wars estão mais próximas dogênero de "fantasia mitopoética"73 ou "alta fantasia" - como as clássicas estórias do universo de O Senhor dos Anéis de J. R. R. Tolkien (1892-1973) ou As Crônicas de Nárnia e a Trilogia de Ranson de C. S. Lewis (1898-1963),

72 Star Wars: Episódio III - A Vingança dos Sith. A partir de 1:43:48.

${ }^{73}$ Utilizamos a definição de Marek Oziewicz, segundo a qual "a fantasia mitopoética é: 1) uma narrativa ficcional, 2) sobre aventuras de heróis psicologicamente humanos, 3) no mundo secundário - e, às vezes, também no mundo primário, 4) construídas a partir de uma variedade de materiais míticos artisticamente re-imaginados, apresentados como verdadeiros segundo critérios realistas, 5) e escritos para criar uma experiência imaginativa de um mundo onde os conceitos metafísicos são realidades objetivas - normalmente corporificados em personagens numinosas - e a resposta do protagonista aos dilemas morais e éticos pretendem mostrar por que tais imperativos morais no mundo primário exigiriam determinados tipos de comportamento". Ver: OZIEWICZ, Marek. Prolegômenos à Fantasia Mitopoética. Trad. Márcia Xavier de Brito. COMMUNIO: Revista Internacional de Teologia e Cultura, Vol. XXVIII, No. 1 (Ed. 101 / Jan.-Mar. 2009): 121-49. Cit. p. 138. bem como, as sagas mais recentes como O Ciclo de Terramar de Ursula K. Le Guin, Harry Potter de J. K. Rowling ou As Crônicas de Gelo e Fogo de George R. R. Martin, dentre outras - do que das inúmeras obras, literárias ou cinematográficas, de ficção científica ${ }^{74}$. $\mathrm{Na}$ primeira parte do presente ensaio defendemos que o gênero de Star Wars é o que se convencionou denominar como Space Opera ${ }^{75}$, que, dentre outras criações, inclui os livros da série Barsoom de Edgar Rice Burroughs (1875-1950), as estórias em quadrinhos de Buck Rogers de Philip Francis Nowlan (1888-1940) e de Flash Gordon de Alex Raymond (1909-1956), bem como os filmes e seriados de TV inspirados nessas aventuras, e, finalmente, os seriados de TV e os filmes do universo de Star Trek [Jornada nas Estrelas] de Gene Roddenberry (1921-1991). O próprio George Lucas reconheceu ${ }^{76}$. A definição de Star Wars como uma Space Opera nos permite entender o porquê da repetição de certos temas. Sobre esse assunto, explica George Lucas:

Os filmes são compostos como se fosse música, onde vários temas acontecem. Os temas se repetem com orquestrações diferentes. [...] E tudo orquestrado como uma obra musical, onde você tem um tema melódico que é usado continuamente ${ }^{77}$.

Nesse sentido, podemos ver que a tentativa de Darth Vader corromper Padmé, se repete, quando ele tenta fazer o

${ }^{74}$ A questão que foi apenas mencionada na já citada primeira parte do presente ensaio, ocupou um espaço maior de reflexão no seguinte texto: CATHARINO. A Imaginação Moral em Star Wars. p. 222-27.

${ }^{75}$ CATHARINO. A Filosofia da Liberdade na Saga de Filmes Star Wars - Parte 1. p. 266-67.

${ }^{76} \mathrm{O}$ reconhecimento da série por seu criador como uma Space Opera aparece, dentre outros lugares, na entrevista para o documentário Empire of Dreams: The History of The Star Wars Trilogy [O Império dos Sonhos: A História da Trilogia Star Wars], dirigido por Edith Becker e Kevin Burns, que acompanha a já citada edição de 2004 em quatro DVDs dos filmes Episódio IV: Uma Nova Esperança, Episódio V: O Império Contra-Ataca e Episódio VI: O Retorno de Jedi.

${ }^{77}$ Declarações feitas nos comentários de áudio ao filme Star Wars: Episódio I - A Ameaça Fantasma. 
mesmo com Luke Skywalker no seguinte diálogo:

[Vader]: Você não tem saída. Não me obrigue a destruí-lo. Luke você não percebe a sua importância. Você apenas começou a descobrir os seus poderes. Junte-se a mim e eu terminarei o seu treinamento. Com nossas forças podemos terminar esse conflito nefasto e pôr ordem na Galáxia.

[Luke]: Nunca irei me juntar a você!

[Vader]: Se ao menos você conhecesse o poder do Lado Negro. Obi-Wan nunca contou o que aconteceu com o seu pai?

[Luke]: Ele me contou o suficiente! Ele disse que você o matou.

[Vader]: Não. Eu sou o seu pai.

[Luke]: Não. Não. Não é verdade. Isso é impossível!

[Vader]: Analise seus sentimentos. Você sabe que é verdade.

[Luke]: Não! Não!

[Vader]: Luke, você pode destruir o Imperador. Ele já previu isso. É o seu destino. Junte-se a mim. Junto poderemos governar a Galáxia como pai e filho. Venha comigo. É sua única saída ${ }^{78}$.

Podemos nos questionar sobre a aparente mentira contada por Obi-Wan Kenobi para Luke acerca do que aconteceu com seu pai ${ }^{79}$. Mas, como explicou o Mestre Yoda, antes de morrer, o que, de fato, Obi-Wan fez foi tentar preservar Luke desse pesado fardo, antes que ele estivesse preparado para carregá-lo, o que pode ser visto no seguinte diálogo entre Luke e o espírito de Obi-Wan:

[Luke]: Por que não me contou? Contou-me que Vader traiu e matou o meu pai.

[Obi-Wan]: Seu pai foi seduzido pelo Lado Negro da Força. Deixou de ser Anakin Skywalker e tornou-se Darth Vader. Quando isso aconteceu, o bom homem que era seu pai foi destruído. Então e que lhe contei era verdade de certo ponto de vista ${ }^{80}$.

\footnotetext{
${ }^{78}$ Star Wars: Episódio V-O Império Contra-Ataca. A partir de 1:50:25.

${ }^{79}$ Star Wars: Episódio IV - Uma Nova Esperança. A partir de 0:32:36.

${ }^{80}$ Star Wars: Episódio VI - O Retorno de Jedi. A partir de 0:45:58.
}

Por outro lado, percebemos que a utilização da mentira e da malícia como meios de persuasão e a defesa do relativismo moral são instrumentos empregados constantemente pelos Sith. Vejamos um exemplo dessa postura no seguinte diálogo entre Palpatine e Anakin:

[Palpatine]: Tente se lembrar de meus primeiros ensinamentos para você: todos que adquirem o poder têm medo de perdêlo. Até mesmo um Jedi.

[Anakin]: Um Jedi usa seus poderes para o bem.

[Palpatine]: Bem é um ponto de vista, Anakin. Os Sith e os Jedi são parecidos em quase tudo... incluindo a busca por mais poder.

[Anakin]: Os Sith contam com uma paixão pela força e só pensam em si próprios.

[Palpatine]: E os Jedi não?

[Anakin]: Os Jedi são altruístas, eles só se importam com os outros.

[Palpatine]: Já ouviu falar na tragédia de Darth Plagueis, o sábio?

[Anakin]: Não.

[Palpatine]: Imaginei que não. Um Jedi não contaria essa história para você. É uma lenda Sith. Darth Plagueis era um Lorde das Trevas dos Sith, tão poderoso e tão sábio que podia usar a Força para influenciar os midichlorians a criar vida. Ele tinha um tal conhecimento do Lado Negro que podia até manter vivos aqueles com quem se importava.

[Anakin]: Ele podia mesmo salvar as pessoas da morte?

[Palpatine]: O Lado Negro da Força é um caminho para muitas habilidades que alguns não consideram como naturais.

[Anakin]: O que aconteceu com ele

[Palpatine]: Ele se tornou tão poderoso que a única coisa que tinha medo era de perder seu poder... o que, finalmente, acabou acontecendo. Infelizmente, ele ensinou ao seu aprendiz tudo o que sabia. Então o aprendiz o matou enquanto ele dormia. É uma ironia. Ele podia salvar os outros da morte, mas não a si próprio.

[Anakin]: É possível aprender a ter esse poder?

[Palpatine]: Não de um Jedi ${ }^{81}$.

${ }^{81}$ Star Wars: Episódio III - A Vingança dos Sith. A partir de 0:45:15. 
Palpatine recorre aqui ao que Russell Kirk, a partir de uma percepção na obra After Strange Gods [Em Busca de Deuses Estrangeiros] $^{82}$ de T. S. Eliot (1888-1965), classificou como "imaginação diabólica", que, por não aceitar nenhum critério objetivo de diferenciação entre o bem e o mal, tende a se deleitar com o que é "perverso e sub-humano"83. O relativismo moral é um dos principais fatores para a emergência dos modernos regimes totalitários, pois como destacou o saudoso papa São João Paulo II (1920-2005) na seguinte passagem da encíclica Centesimus Annus (1ํㅡㄹ de maio de 1991):

Se não existe nenhuma verdade última que guie e oriente a ação política, então as ideias e as convicções podem ser facilmente instrumentalizadas para fins de poder. Uma democracia sem valores convertese facilmente num totalitarismo aberto ou dissimulado, como a história demonstra. [...] Num mundo sem verdade, a liberdade perde a sua consistência, e o homem acaba exposto à violência das paixões e a condicionalismos visíveis ou ocultos $(C A \S 46)^{84}$.

Mais uma vez, ressaltamos que não há conflitos entre a posição conservadora, que busca defender os mais profundos valores da tradição contra o relativismo moral, e a postura libertária, que almeja proteger a liberdade dos avanços do poder estatal ${ }^{55}$. De

${ }^{82}$ ELIOT, T. S. After Strange Gods: A Primer of Modern Heresy. Londres: Faber and Faber, 1934. p. 56-57.

${ }^{83}$ KIRK. A Imaginação Moral. p. 105.

${ }^{84}$ JOÃO PAULO II, Papa. Carta Encíclica Centesimus Annus: Sobre a Questão Social no Centenário da Rerum Novarum. São Paulo: Paulinas, 3ª Ed., 1991.

${ }^{85}$ A temática foi discutida de modo mais sistemático em: CATHARINO. A Escola Austríaca entre a Tradição e a Inovação. p. 305-23. Acreditamos ser importante ressaltar que em questões morais e culturais a maioria dos pensadores austríaco defenderam posições conservadoras, se opondo ao relativismo moral e defendendo a tradição ética da Civilização Ocidental. Para maiores informações sobre a postura conservadora de Ludwig von Mises e de F. A. Hayek, consultar os seguintes ensaios: TUCKER, Jeffrey A. \& ROCKWELL JR., Llewellyn H. O Pensamento Cultural de Ludwig certo modo, as mazelas de nossa época são fruto de uma aliança entre o intervencionismo estatal e o relativismo moral. Sobre essa temática, afirmou o pensador libertário HansHermann Hoppe:

Em todo caso, o que deve estar claro agora é que a maior parte - se não a totalidade - da degradação moral e da podridão cultural as quais são os sinais de descivilização - que verificamos ao nosso redor são os resultados inevitáveis e inescapáveis do Estado de bem-estar social (assistencialista) e das suas principais instituições. Os conservadores clássicos, ao estilo antigo, sabiam disso; e eles se opuseram vigorosamente à educação pública e à previdência social. Eles sabiam que os estados em tudo quanto é lugar intencionavam deteriorar - e, em última análise, destruir - as famílias (bem como as instituições, as camadas e as hierarquias de autoridade que são a consequência natural das comunidades baseadas em famílias) para, então, aumentar e reforçar o seu próprio poder. Eles sabiam que, a fim de fazê-lo, os Estados teriam de tirar proveito da revolta natural dos adolescentes (dos jovens) contra a autoridade paternal. E eles sabiam que a educação socializada e a responsabilidade socializada eram os meios de atingir essa meta. A educação pública e a previdência social fornecem uma possibilidade para os jovens rebeldes de escapar da autoridade paternal (de escapar de punições por comportamentos impróprios). Os velhos conservadores sabiam que essas políticas emancipariam o indivíduo da disciplina imposta pela vida familiar e comunitária apenas para submetêlo, em vez disso, ao controle direto e imediato do Estado. Adicionalmente, eles sabiam - ou pelo menos tinham um palpite sobre isso - que tais práticas conduziriam a uma infantilização sistemática da sociedade - a

von Mises. Trad. Davi J. Dias. MISES: Revista Interdisciplinar de Filosofia, Direito e Economia, Vol. I, No. 1 (Jan.-Jun. 2013): 191-213; FESER, Edward. Hayek on Tradition. Journal of Libertarian Studies, Vol. 17, No. 1 (Winter 2003): 17-56; SCRUTON, Roger. Hayek and Conservatism. In: FESER, Edward (Ed.) Cambridge Companion to Hayek. Cambridge: Cambridge University Press, 2007. p. 208-31. 
um retrocesso, tanto em termos emocionais quanto em termos mentais (intelectuais), da idade adulta para a adolescência ou a infância ${ }^{86}$.

Os riscos de nossas democracias se transformarem em ditaduras, por conta do assistencialismo governamental e da degeneração moral e cultural promovidos pelo Estado de Bem-Estar Social e pela proletarização dos membros da sociedade, são bem maiores do que uma parcela significativa das pessoas imagina ${ }^{87}$. Em 1835, no segundo livros da obra De la démocratie en Amérique [A Democracia na América], Alexis de Tocqueville (1806-1859) nos alertou para esse problema com as seguintes palavras:

Procuro descobrir sob que traços novos o despotismo poderia ser produzido no

${ }^{86}$ HOPPE, Hans-Hermann. Democracia, o deus que falhou: A Economia e a Política da Monarquia, da Democracia e da Ordem Natural. Trad. Marcelo Werlang de Assis. São Paulo: Instituto Ludwig von Mises Brasil, 2014. p. 233-35.

87 Além dos já citados livros Uma Crítica ao Intervencionismo e Intervencionismo: Uma Análise Econômica de Ludwig von Mises, para uma visão sintética do problema do Estado de Bem-Estar Social aconselhamos a leitura do seguinte trabalho: HAZLITT, Henry. Man vs. The Welfare State. New York: Arlington House, 1969. A clássica obra de F. A. Hayek, publicada originalmente em 1944, apresenta como tese central a eminente ameaça do intervencionismo estatal servir como meio de implementação de uma nova forma de "despotismo brando", em detrimento da liberdade individual. Em língua portuguesa, consultar: HAYEK, F. A. O Caminho da Servidão. Trad. Anna Maria Capovilla, José Ítalo Stelle e Liane de Morais Ribeiro. São Paulo: Instituto Ludwig von Mises Brasil,

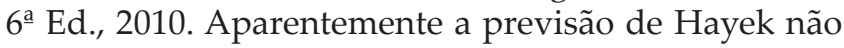
se concretizou, no entanto, ao estudarmos o fenômeno da proletarização e da emergência da chamada "subclasse", tal como analisados, respectivamente, por Russell Kirk e por Theodore Dalrymple - este último o pseudônimo do ensaísta e médico psiquiatra Anthony Daniels - podemos verificar que a realidade atual é mais sombria do que profetizada em 1944 no livro O Caminho da Servidão. Ver: KIRK. Perspectivas do Proletariado. In: A Política da Prudência. p. 313-29; DALRYMPLE, Theodore. A Vida na Sarjeta: O Círculo Vicioso da Miséria Moral. Trad. Márcia Xavier de Brito. São Paulo: É Realizações, 2014. mundo: vejo uma multidão inumerável de homens semelhantes e iguais, que sem descanso se voltam sobre si mesmo à procura de pequenos e vulgares prazeres, com os quais enchem a alma. Cada um deles, afastado dos demais, é como um estranho ao destino de todos os outros [...]. Acima destes, eleva-se um poder imenso e tutelar, que se encarrega sozinho de garantir o seu prazer e velar sobre sua sorte. É absoluto, minucioso, regular, previdente e brando. [...] Agrada-lhe que os cidadãos se rejubilem, desde que não pensem senão em se rejubilar. Trabalha de bom grado para sua felicidade, mas deseja ser o seu único agente e árbitro exclusivo [...]. É assim que, todos os dias, torna menos útil e mais raro o emprego do livre arbítrio; é assim que encerra a ação da vontade num pequeno espaço e, pouco a pouco, tira cada cidadão até o emprego de si mesmo. A igualdade preparou os homens para todas essas coisas, dispondo-os a sofrer e muitas vezes até a considerá-las como um benefício. [...] Nesse sistema, os cidadãos por um momento abandonam a dependência, para indicar o seu senhor, e depois voltam a ela. Hoje em dia, há muitas pessoas que se acomodam muito facilmente a essa espécie de compromisso entre o despotismo administrativo e a soberania do povo, e que pensam ter garantido suficientemente a liberdade dos indivíduos, quando é ao poder nacional que a entregam ${ }^{88}$.

Em muitos aspectos a democracia foi sobrevalorizada como um instrumento de defesa da ordem, da liberdade e da justiça, criando uma ideologia do democratismo que transforma tal processo de escolhas políticas em um fim em si mesmo, o que acarreta em risco para os próprios princípios sociais que se almejava preservar, tal como foi denunciado por Russell Kirk no capítulo “Governo Popular e Mentes Imoderadas" do livro The Politics of

${ }^{88}$ TOCQUEVILLE, Alexis Charles Henri Maurice Clérel de. A Democracia na América. Pref. Antônio Paim; Trad. e notas Neil Ribeiro da Silva. Belo Horizonte: Editora Itatiaia, 1987. Livro II, Quarta Parte, Cap. VI, p. 531. 
Prudence [A Política da Prudência] ${ }^{89}$. A crítica kirkeana, em alguns aspectos, assemelhase à posição conservadora apresentada por Erik von Kuehnelt-Leddihn (1909-1999) nas obras Liberty or Equality: The Challenge of Our Time [Liberdade ou Igualdade: O Desafio de Nossa Época] ${ }^{90}$ e Leftism Revisited: From de Sade and Marx to Hitler and Pol Pot [Esquerdismo Revisitado: De Sade e Marx a Hitler e Pol Pot $]^{91}$, que influenciaram profundamente diversos aspectos da perspectiva libertária acerca do tema tal como defendida pelo supracitado Hans-Hermann Hoppe ${ }^{92}$. Como, de modo incisivo, asseverou Kirk:

No início do século $\mathrm{XX}$, poucos Estados no mundo podiam ser considerados democráticos; contudo, existia muita liberdade pessoal e local, sob o império da lei. Perto do final do século XX, quase todos os regimes políticos mundo afora professam ser democráticos; entretanto, em vários países, a liberdade pessoal e local foi extirpada. Ao que parece, o triunfo da democracia, longe de preservar ou expandir a liberdade, levou ao poder uma multidão de oligarcas miseráveis ${ }^{93}$.

O modo como um regime democrático pode servir aos anseios de um tirano é demonstrado com maestria nas famosas sequências em que Palpatine discursa no Senado, enquanto Padmé Amidala conversa com o Senador Bail Organa, que chegou atrasado na sessão por conta de ter estado ocupado ajudando a resgatar Yoda e ObiWan Kenobi do ataque das tropas de clones

\footnotetext{
${ }^{89}$ KIRK. Governo Popular e Mentes Imoderadas. In: A
} Política da Prudência. p. 331-43.

90 KUEHNELT-LEDDIHN, Erik von. Liberty or Equality: The Challenge of Our Time. Ed. John P. Hughes. Caldwell: The Caxton Printers, 1952.

${ }^{91}$ Idem. Leftism Revisited: From de Sade and Marx to Hitler and Pol Pot. Washington, D. C.: Regnery Gateway, 1990.

${ }^{92}$ HOPPE. Democracia. p. 16, 49, 81, 84, 137, 162, 213, 224, 268, 293.

${ }^{93}$ KIRK. Governo Popular e Mentes Imoderadas. In: A Política da Prudência. p. 331. contra os Jedi e a infiltrar estes dois fugitivos na capital:

[Palpatine discursando]: A rebelião Jedi foi debelada.

[Bail Organa para Padmé]: O que aconteceu? [Padmé para Bail]: O Chanceler fala de complô Jedi para derrubar a República.

[Palpatine discursando]: Os Jedi remanescentes serão perseguidos e derrotados!

(Aplausos ao fundo) $)^{94}$

[...]

[Palpatine discursando]: $\mathrm{O}$ atentado contra à minha vida me deixou com cicatrizes e deformações. Mas asseguro a vocês que nunca estive tão fortalecido!

(Aplausos ao fundo) ${ }^{95}$

[...]

[Palpatine discursando]: A fim de garantir a segurança e manter a estabilidade, a República será reorganizada e convertida no Primeiro Império Galáctico para uma segura e tranquila sociedade!

(Aplausos efusivos)

[Padmé para Bail]: Então, é assim que morre a liberdade. Com um estrondoso aplauso ${ }^{96}$.

Além do problema, aparentemente, intrínsecos às democracias modernas de servir ao avanço do controle estatal em detrimento da liberdade individual, o grande risco que nossas sociedades ocidentais enfrentam, num contexto cultural marcado pelo relativismo e pelo hedonismo, é o avanço da "desagregação normativa" propagada pelo igualitarismo, pelo intervencionismo e pelo democratismo, que, como ressaltou Russell Kirk, nos faz sucumbir "à tirania da padronização sem padrões" 97 . Vivemos

${ }^{94}$ Star Wars: Episódio III - A Vingança dos Sith. A partir de 1:34:00.

${ }^{95}$ Star Wars: Episódio III - A Vingança dos Sith. A partir de 1:35:13.

${ }^{96}$ Star Wars: Episódio III - A Vingança dos Sith. A partir de 1:35:41.

97 KIRK, Russell. A Arte Normativa e os Vícios Modernos. Trad. Gustavo Santos, notas Alex Catharino. COMMUNIO: Revista Internacional de Teologia e Cultura, Vol. XXVII, No. 4 (Ed. 100 / Out.-Dez. 2008): 993-1017. Cit. p. 1005. 
atualmente em um mundo, que pela ausência de normas objetivas, é marcado por "uma visão desumana da vida", que fundamenta "uma ordem social desumana" ${ }^{\prime \prime}$. Nesse sentido, Darth Vader pode ser visto como uma alegoria do homem moderno, que vendeu a alma para o diabo e se tornou parte do sistema, não desenvolvendo a própria humanidade. Como destacou Joseph Campbell, Darth Vader é um burocrata que "vive não nos seus próprios termos, mas nos termos de um sistema imposto"99.

O conflito existencial entre a "primeira realidade" e a "segunda realidade" vivido por Anakin Skylwalker foi alimentado pelos vícios da soberba, da vanglória, da tibieza, da temeridade, do ciúme e da ira, que associados ao sentimentalismo infantil que o impedia de aceitar as mudanças e perdas impostas pela realidade foram os fatores decisivos para este herói trágico ser manipulado e seduzido por Palpatine, que o transformou no vilão Darth Vader, uma criatura má e desorientada, mais máquina do que homem. Vader acreditava ser o senhor do próprio destino, quando, na verdade, era apenas uma marionete controlada e enganada pelas maquinações astuciosas de Palpatine, tal como expresso no diálogo travado entre os dois após todos os líderes da Confederação de Sistemas Independentes serem assassinados:

[Vader]: Eu já cuidei dos separatistas, meu mestre.

[Palpatine]: Então, está terminado. Você restaurou a paz e a justiça na Galáxia. Mande uma mensagem às naves da Federação de Comércio. Todas as unidades droides devem ser desligadas imediatamente.

[Vader]: Muito bem, Milorde ${ }^{100}$.

Anakin Skywalker se deixou seduzir pelas mentiras de Palpatine, aceitando a ideia relativista de que não existe a verdade e o bem objetivos. Ao se tornar Darth Vader, Anakin

\footnotetext{
${ }^{98}$ Idem. Ibidem. p. 995.

${ }^{99}$ CAMPBELL \& MOYERS. O Poder do Mito. p. 153.

100 Star Wars: Episódio III - A Vingança dos Sith. A partir de $1: 42: 20$.
}

se assemelhou ao homem marcado pelo pecado, que tenta levar outras pessoas para o mesmo caminho errado que está trilhando ${ }^{101}$. Somente, por ainda existir uma centelha do bem em sua alma é que ele pode ser redimido pelo sacrifício de amor do filho, se libertando do mal ${ }^{102}$. Tal redenção foi possível porque Luke Skywalker não se deixou seduzir pelas falsas promessas de poder, feitas por Darth Vader $^{103}$ ou pelo Imperador Palpatine ${ }^{104}$.

No entanto, existe uma importante diferença entre Palpatine e Anakin em relação ao modo como buscaram conquistar o poder. Todas as tramas de Palpatine tinham como finalidade alcançar o poder absoluto apenas pelo desejo de subjugar todos à sua vontade. No caso de Anakin, o desejo de adquirir o poder foi um mero meio para tentar salvar a vida da pessoa amada e, ao mesmo tempo, um artifício para trazer ordem à sociedade, implantando a paz e a justiça. Em termos morais a finalidade dos atos do primeiro era intrinsecamente má, ao passo que com o segundo o problema reside na busca de meios errados para atingir fins corretos, o que não deixa de ser moralmente reprovável. Anakin se tornou uma vítima dos planos de Palpatine porque tentou, por seus próprios meios, solucionar os problemas da realidade que o cercava.

${ }^{101}$ Sobre a temática da proliferação do pecado o Catecismo da Igreja Católica faz a seguinte afirmação: "O pecado cria uma propensão pelo pecado; gera o vício pela repetição dos mesmos atos. Disso resultam inclinações perversas que obscurecem a consciência e corrompem a avaliação concreta do bem e do mal. Assim, o pecado tende a reproduzir-se e a reforçar-se, mas não consegue destruir o senso moral até a raiz" (§1865). Utilizamos aqui, a seguinte edição brasileira: Catecismo da Igreja Católica. Edição Típica Vaticana. São Paulo: Loyola, 2000.

102 Ver o filme Star Wars: Episódio VI - O Retorno de Jedi. Ver, também, o livro: KAHN. Star Wars: Episode VI Return of Jedi.

${ }^{103}$ Ver o filme Star Wars: Episódio V - O Império ContraAtaca. Ver, também, o livro: GLUT. Star Wars: Episode V - The Empire Strikes Back.

${ }^{104}$ Ver o filme Star Wars: Episódio VI - O Retorno de Jedi. Ver, também, o livro: KAHN. Star Wars: Episode VI Return of Jedi. 
A tragédia de Anakin Skywalker / Darth Vader se assemelha ao drama da mente moderna indisciplinada, que, nas palavras de Russell Kirk, "imaginando perseguir fatos, muitas vezes segue uma vela de defunto até a beira do abismo - e, às vezes, por sobre essa beira". Para Kirk:

Se o homem depender apenas de seus poderes racionais privados, ele perderá a sua fé - e talvez o mundo, também, arriscando a sua própria natureza num jogo de xadrez contra o Diabo. Mas se o homem se fortifica com disciplinas normativas, se vale da imaginação e das lições do passado, e por isso é capaz de confrontar mesmo um adversário diabólico ${ }^{105}$.

Nas jornadas de Anakin e de Luke existe uma diferença fundamental entre a postura dos dois, que em última instância determinou o fato do primeiro ter se tornado um trágico herói decaído e do segundo ter assumido o papel arquetípico de herói redentor. O filho na luta contra o mal se voltou para a tradição, ao seguir os ensinamentos dos mestres ObiWan Kenobi e Yoda. O pai, por uma boa causa, tentou depender apenas de suas capacidades, voltou-se contra os amigos, e adotou meios reprováveis, que o levaram a se aliar ao que prometeu combater, sucumbindo às falsas promessas de Palpatine / Darth Sidious, que representa o arquétipo do tentador.

O tentador costuma utilizar com frequência a oferta de poder político como meio de corromper a alma do homem, lembremos que, de acordo com as narrativas de São Mateus (Mt 4,8-9) e de São Lucas (Lc 4,5-7), o próprio Jesus Cristo recebeu essa proposta de Satanás. Uma bela alegoria acerca dos riscos do homem moderno perder a alma barganhando por poder político, se encontra na peça Murder in the Cathedral [Assassínio na Catedral] de T. S. Eliot, na qual o para criticar a emergência dos regimes totalitários tanto de esquerda quanto de direita na década de 1930, o autor utiliza uma narrativa poética dos eventos históricos que levaram a morte

${ }^{105}$ KIRK. A Arte Normativa e os Vícios Modernos. p. 1011. de Santo Thomas Becket (1118-1170), quando o bispo recusou trair a fé e se reconciliar com o despótico rei Henry II (1133-1189) para salvar a própria vida. Um dos pontos centrais da defesa elioteana da liberdade de consciência, contra a perversão ideológica e as promessas de poder político, é expressa na seguinte passagem:

O poder temporal de melhorar o mundo, Manter a ordem, como o mundo a entende... Aqueles que põem fé na lei do mundo Não controlada pela lei de Deus,

Em sua altiva ignorância só provocam desordem,

Tornando-a mais rápida, procriam doenças fatais, Degradam aquilo que exaltam. Compartilhar o poder com o Rei...

Eu era o Rei, era seu braço, sua melhor razão.

Mas o que já foi exaltação

Seria agora degradação apenas ${ }^{106}$

O caráter de um homem pode ser julgado pelo modo que se porta diante da oferta de assumir o poder político. Ao analisarmos em outro ensaio a saga $O$ Senhor dos Anéis de J. R. $R$. Tolkien, afirmamos que:

Em nosso mundo, precisamos evitar os ditamesdiabólicosdo poder, principalmente, a tentativa ingênua de usar a máquina estatal para implantar medidas aparentemente benéficas para a comunidade, mas, que, na prática, terão como único resultado a restrição da liberdade individual em nome da segurança, da paz, do bem-comum, da moralidade, da prosperidade ou de qualquer outro princípio louvável ${ }^{107}$.

106 ELIOT, T. S. Assassínio na Catedral. In: T. S. Eliot: Obra Completa - Volume II: Teatro. Edição bilíngüe com texto original em inglês e tradução para o português de Ivo Barroso. São Paulo; Arx, 2004. p. 35. Para uma interpretação da peça, ver: KIRK. A Era de T. S. Eliot. p. 403-16.

107 CATHARINO, Alex. A Imaginação Moral de J. R. $\mathrm{R}$. Tolkien e os Conceitos de Liberdade na Trilogia $O$ Senhor dos Anéis. MISES: Revista Interdisciplinar de Filosofia, Direito e Economia, Vol. I, No. 1 (Jan.-Jun. 2013): 215-54. Cit. p. 236. 
Em seguida, ressaltamos o fato de que "o verdadeiro defensor da liberdade não deve ceder às tentações do poder"108, para citar os exemplos de Ludwig von Mises e de Russell Kirk, que reconheceram os riscos inerentes à tentativa de utilizar do poder governamental como meio de implementar a causa da liberdade. Kirk foi convidado tanto pelo presidente Richard Nixon (1913-1994) quanto pelo presidente Ronald Reagan (1911-2004) para assumir postos na administração pública federal norte-americana, no entanto, declinou de tais propostas dizendo ironicamente para o primeiro que "poderia ter tido esse tipo de cargo quando tinha trinta anos, se desejasse", e brincando com o segundo afirmou: "como deves odiar-me para tentar transformar-me num burocrata"109. Em uma festa na residência do economista Leonard E. Read (1898-1983), na década de 1940, Mises foi questionado por um dos convidados sobre o que faria na hipótese de ser nomeado ditador dos Estados Unidos, gozando da possibilidade de impor as medidas que desejasse. A resposta imediata do economista austríaco foi: " $E u$ renunciaria!"110. Como sabiamente alertou J. R. R. Tolkien: "você não pode enfrentar o Inimigo com o Anel dele sem se tornar o Inimigo"111. De modo semelhante, George Lucas afirmou que:

Se você quer um maior poder, deve passar ao lado mais forte, que aparentemente é o Lado Negro, mas a decisão será sua. Mas essa fome de poder e a necessidade do

\footnotetext{
${ }^{108}$ Idem. Ibidem., p. 236.

${ }^{109}$ KIRK, Russell. The Sword of Imagination: Memoirs of a Half-Century of Literary Conflict. Grand Rapids, William B. Eerdmans Publishing Company, 1995. p. 435.

${ }^{110}$ HÜLSMANN, Jörg Guido. Mises: The Last Knight of Liberalism. Alburn: Ludwig von Mises Institute, 2007. p. 824. Citado, originalmente, em: SENNHOLZ, Mary. Leonard E. Read: Philosopher of Freedom. Irvington-on Hudson: Foundation for Economic Education, 1993. p. 145.

111 TOLKIEN. As Cartas de J. R. R. Tolkien. Org. Humphrey Carpenter, com a assistência de Christopher Tolkien; Trad. Gabriel Blum Oliva. Curitiba: Arte e Letra Editora. 2006. p. 95.
}

poder são para satisfazer à sua ambição de não abdicar das coisas e permitir o curso natural da vida, que é de que as coisas vêm e vão. O correto é ser capaz de aceitar as mudanças que acontecem com você, e não querer manter os momentos congelados no tempo eternamente ${ }^{112}$.

Já em 1927, muito antes da primeira apresentação da peça Assassínio na Catedral de Eliot em 1ํ de novembro de 1935 e da publicação dos três volumes da saga O Senhor dos Anéis de Tolkien entre 29 de julho de 1954 e 20 de outubro de 1955, o problema da sedução pelo poder na tentativa de criar "um mundo melhor" foi descrito por Ludwig von Mises, no livro Liberalismus [Liberalismo], com as seguintes palavras:

Verificamos que, ao abrirmos mão do princípio de que o Estado não deve interferir em quaisquer questões que tocam o modo de vida do indivíduo, terminamos por regulá-lo e restringi-lo aos mínimos detalhes. Abolese a liberdade pessoal do indivíduo! Ele se torna um escravo da comunidade, obrigado a obedecer aos ditados da maioria. Não é necessário divagar sobre as maneiras pelas quais tais poderes poderiam ser utilizados até ao abuso por autoridades malévolas. $\mathrm{O}$ exercício de poderes desse tipo, mesmo por homens imbuídos das melhores intenções, necessariamente, reduziria o mundo a um cemitério do espírito ${ }^{113}$.

Acreditamos que este "cemitério do espírito" descrito por Ludwig von Mises se assemelha à doença retratada por T. S. Eliot nos poemas The Waste Land [A Terra Desolada], de 1922, e The Hollow Men [Os Homens Ocos], de $1925^{114}$. A mazela intelectual descrita

\footnotetext{
${ }^{112}$ Declarações feitas nos comentários de áudio ao filme Star Wars: Episódio II - O Ataque dos Clones.

113 MISES, Ludwig von. Liberalismo: Segundo a Tradição Clássica. Trad. Haydn Coutinho Pimenta. São Paulo: Instituto Ludwig von Mises Brasil, 2ª Ed., 2010. p. 79

114 Os dois poemas estão disponíveis no original em inglês e com uma tradução versificada para o português na seguinte edição brasileira: ELIOT, T. S.
} 
simbolicamente nestes dois poemas foi entendida por Russell Kirk como um inferno ideológico que "pode estar pavimentado de boas intenções", que é explicado com as seguintes palavras:

Esse é o inferno dos intelectuais que põem a confiança 'naquela parte do presente que já está morta'; é o inferno do oportunista na política; é o inferno do homem sensual mediano que prefere a diversão efêmera ao amor pelo dever e sacrifício; é o inferno a que descem muitos homens, em todas as épocas; também é o inferno que mais está em conformidade com a infidelidade do século XX. Embora esse não seja o inferno da imaginação diabólica, certamente é o inferno para o qual a imaginação idílica nos seduz; é um inferno em que ninguém reina: nem mesmo o Grande Anarquista pode ser avistado $^{115}$.

Um dos acontecimentos mais dramáticos do século XX, tal como descrito por F. A. Hayek, foi "a mudança estrutural da sociedade, implícita na vitória do ideal de segurança sobre $o$ de independência"116. Esta transformação ideológica reduziu drasticamente as liberdades individuais nas democracias ocidentais, fazendo, nas palavras de J. R. R. Tolkien, que a maioria dos "adoradores do Deus-Estado" expandissem o domínio governamental sobre a sociedade e passassem a viver "em paz e abundância e em estima $e$ confiança mútuas"117. Hayek relata o problema da seguinte maneira:

Numa sociedade em que o indivíduo conquista posição e honras quase exclusivamente em função de ser um servidor assalariado do governo; em que o cumprimento do dever prescrito é considerado mais louvável do que a escolha do próprio campo de atividade; em que

T. S. Eliot: Obra Completa - Volume I: Poesia. Edição bilíngüe com texto original em inglês e tradução para o português de Ivan Junqueira. São Paulo; Arx, 2004.

${ }^{115}$ KIRK. A Era de T. S. Eliot. p. 279.

${ }^{116}$ HAYEK. O Caminho da Servidão. p. 136.

${ }^{117}$ TOLKIEN. As Cartas de J. R. R. Tolkien. p. 234. todas as ocupações que não conferem um lugar na hierarquia oficial ou o direito a um rendimento fixo são julgadas inferiores e até certo ponto aviltantes - seria demais esperar que a maioria prefira por muito tempo a liberdade à segurança. E quando só se pode optar entre a segurança numa posição de dependência e a extrema precariedade numa situação em que tanto o fracasso com o êxito são desprezados, poucos resistirão à tentação da segurança ao preço da liberdade. Tendo-se chegado a esse ponto, a liberdade torna-se quase um objeto de escárnio, pois só pode ser alcançada com o sacrifício de grande parte das boas coisas da vida. Nessas condições, não surpreende que um número cada vez maior de pessoas se convença de que sem segurança econômica a liberdade "não vale a pena" e se disponha a sacrificar esta em troca daquela ${ }^{118}$.

Vale lembrar aqui, mais uma vez, o famoso conselho do historiador católico John Emerich Edward Dalberg-Acton (1834-1902), Lorde Acton, que, numa carta, de 5 de abril de 1887, para o bispo anglicano Mandell Creighton (1843-1901), quando afirmou que:

A responsabilidade histórica compensa a carência de responsabilidade jurídica. $\mathrm{O}$ poder tende a corromper, e o poder absoluto corrompe absolutamente. Grandes homens são quase sempre os homens maus, mesmo quando exercem influência e não autoridade, e, ainda mais, quando se acrescenta a tendência ou a certeza de corrupção pela autoridade ${ }^{119}$.

Nesse particular, os ensinamentos da Escola Austríaca, por um lado, fornecem no plano teórico o melhor sextante para orientar a jornada de todos que estejam preocupados com a defesa da ordem, da liberdade e da justiça contra as forças das desumanizadoras potestades coletivistas que dominam o cenário

${ }^{118}$ HAYEK. O Caminho da Servidão. p. 136-37.

119 ACTON, John Emerich Edward Dalberg-. ActonCreighton Correspondence. In: Selected Writings of Lord Acton - Volume II: Essays in the Study and Writing of History. Ed. J. Rufus Fears. Indianapolis: Liberty Classics, 1986. p. 383. 
intelectual e as instituições políticas de nossa época. Em um breve ensaio de divulgação, acentuamos de modo incisivo que:

Ao apresentar de forma clara e objetiva os limites do conhecimento humano e o funcionamento da economia como fruto da livre interação das vontades individuais de inúmeros agentes, com ênfase no papel do indivíduo na sociedade, os autores da Escola Austríaca demonstram não só a falibilidade do planejamento econômico governamental, mas também sua ineficiência e imoralidade, incongruente com a natureza humana ${ }^{120}$.

Por fim, mais uma vez ressaltamos que a saga Star Wars oferece, por outro lado, metáforas que poderão ser apropriadas para explicar melhor os dramáticos acontecimentos do avanço do poder governamental sobre o terreno da liberdade individual. Lembramos que a ordem externa do Império Galáctico era uma estrutura política opressiva e perversa criada pelas maquinações sibilinas de Palpatine. Tal ordenamento era mantido pelo controle dos burocratas e pela violência dos militares, além de refletir as desordens internas da alma de Anakin Skywalker / Darth Vader, que de modo autodestrutivo se rendeu "ao amor possessivo e ao ódio por ciúmes"121. O modelo de ordem representado pelo Império Galáctico, apesar de ser artificial, tentou obter o monopólio sobre a verdade da sociedade, entrando, assim, em um conflito existencial com a maioria dos indivíduos, que, ainda, são apegados à antiga ordem livre da República Galáctica. Saindo do universo da ficção e adentrando em nossa realidade, cabe aos defensores da liberdade, tanto conservadores quanto libertários, romper a tentativa de hegemonia intelectual dos defensores do coletivismo. Mas, para esta empreitada não podemos nos limitar apenas aos aspectos racionais, buscando transformar apenas com argumentos a mentalidade dos defensores de teorias coletivistas, também, precisamos tocar o coração desses indivíduos,

120 CATHARINO, Alex. A Economia do Bom Senso. Revista Vila Nova, Edição 02, mar/abr/mai 2012. p. 38.

${ }^{121}$ PAGLIA. Imagens Cintilantes. p. 191. alimentando a imaginação moral com metáforas que demonstrem a moralidade dos princípios da liberdade. Neste último aspecto, as alegorias apresentadas pelo universo ficcional de Star Wars pode ser um importante aliado em nossa luta.

\section{Conclusão}

Alguns ensinamentos importantes para os defensores da ordem, da liberdade e da justiça foram ressaltados pela saga Star Wars ao longo dos filmes Episódio I: A Ameaça Fantasma, Episódio II: Ataque dos Clones e Episódio III: A Vingança dos Sith, Episódio IV: Uma Nova Esperança, Episódio V: O Império Contra-Ataca, e Episódio VI: Retorno de Jedi. Ressaltamos anteriormente algum desses aspectos do seguinte modo:

A primeira lição é que, apesar de muitas vezes estar oculto, a existência do mal é real e ele age no mundo. Um segundo ponto a ser destacado são os riscos da corrupção pelo poder, principalmente o poder político absoluto. Todavia, a primeira corrupção é a da alma. Podemos nos corromper por boas causas. A corrupção da alma transforma a pessoa num ser desorientado que é levado a lutar, às vezes inconscientemente, contra o que se pretendia defender, fazendo o indivíduo se voltar contra os verdadeiros valores da Tradição. Uma alma desorientada tenta corromper outras pessoas, usando a violência ou a malícia para corrompê-los. Outro ensinamento de Star Wars é que o mal deve ser combatido com os valores e meios adequados, mas, sem nunca se perder a dimensão do princípio da verdade e da caridade, pois, o que está em jogo, nessa luta, é a salvação da alma do homem decaído ${ }^{122}$.

Na já citada análise de Camille Paglia, a escritora norte-americana apresenta os seguintes pontos acerca da criação de George Lucas:

${ }^{122}$ CATHARINO, Alex. A Imaginação Moral em Star Wars. p. 251. 
Embora o enredo e os diálogos talvez sejam relegados ao segundo plano, um simples, mas coerente sistema filosófico permeia os seis filmes de Star Wars. O juvenil liberalismo de Lucas (versus o conservadorismo empedernido do pai) era típico da boêmia baía de São Francisco, um ninho de política radical e psicodelismo da década de 1960. Mas, Lucas é um sujeito descente, que não fuma, nem bebe ou usa drogas [...], ele vive frugalmente, reinvestindo os lucros na produção de filmes. Está implícito o ambientalismo no generoso leque de ecossistemas planetários, férteis ou arrasados; [...]. Lucas professa um interesse multicultural pelas religiões do mundo inteiro, com suas diversas concepções de Deus e do espírito [...]. Enfim, a série assume uma visão cíclica da história, vendo a democracia ser derrota repedidas vezes pelo fascismo e pelo imperialismo, de César a Napoleão e Hitler ${ }^{123}$.

O uso intencional por George Lucas das teorias de Joseph Campbell acerca da narratologia do monomito ${ }^{124}$ oferece critérios universais e multiculturais a partir de arquétipos primordiais $^{125}$, que possibilitam um entendimento mais amplo acerca da natureza humana e dos princípios do ordenamento social, político e econômico. Em uma entrevista para seu discípulo Bill Moyers, foi ressaltado por Joseph Campbell que "A sociedade atual não nos dá a instrução mítica adequada", motivo pelo qual "os jovens têm dificuldades de encontrar o seu caminho $^{\prime 126}$. O cineasta norte-americano, em

\footnotetext{
${ }^{123}$ PAGLIA. Imagens Cintilantes. p. 189.

${ }^{124}$ CAMPBELL, Joseph. O Herói de Mil Faces. Trad. Adail Ubirajara Sobral. São Paulo: Editora Pensamento, $11^{\text {a }}$ Ed., 1995.

${ }^{125}$ AutilizaçãoporGeorgeLucasdateoria danarratologia do monomito elaborada por Joseph Campbell como fundamento saga Star Wars foi analisado de modo mais amplo em: CATHARINO, Alex. A Imaginação Moral em Star Wars. p. 227-32. De modo resumido, abordamos a questão em: CATHARINO. A Filosofia da Liberdade na Saga de Filmes Star Wars - Parte 1. p. 269-68. Ver, também: VOGLER. A Jornada do Escritor. Esp. p. 288-89.

${ }^{126}$ CAMPBELL \& MOYERS. O Poder do Mito. p. 152.
}

uma das inúmeras entrevistas que concedeu para Bill Moyers, reconheceu a importância e a responsabilidade do papel pedagógico exercido por seus filmes com as seguintes palavras: Acredito na filosofia de que todos ensinamos. Nós ensinamos todos os dias de nossas vidas. E não é necessariamente por meio do discurso. Eu descobri que as crianças não gostam de discursos. Trata-se de como vivemos as nossas vidas, o que fazemos com elas e como nos conduzimos. E, às vezes, eles escutam os discursos. Então, quando eu faço os filmes, estou ciente do fato de estar ensinando numa escala maior do que apenas sendo um pai, ou qualquer outra pessoa. Porque eu tenho este megafone, qualquer pessoa na mídia tem um megafone com o qual pode atingir muitas pessoas diferentes. Então, o que eles dizem, fazem, como se comportam e o que produzem tem uma influência. Estão ensinando alguém. E eu tento ter cuidado com o que estou falando ${ }^{127}$.

O impacto deste trabalho para a educação artística e para a formação moral de inúmeras gerações de jovens no mundo inteiro é incomensurável, pois, como já ressaltamos, "a série de filmes Star Wars, criada pelo cineasta norte-americano George Lucas, já faz parte do imaginário da civilização ocidental"128. A importância dos princípios éticos e estéticos veiculados pelos filmes da série é destacado, na análise das cenas finais do Episódio III: A Vingança dos Sith, por Camille Paglia do seguinte modo:

O filme termina com o nascimento dos gêmeos Luke e Leia, dezenove anos antes de aparecerem como jovens adultos no filme Star Wars original. Paralelamente ao nascimento dos bebês, durante o qual a mãe morre, aparece o nascimento torturado, cibernético, de Darth Vader como o monstro de Frankestein em seu laboratório, agora assessorado por impiedosos androides cirurgiões. Por fim, depois de cerca de trin-

\footnotetext{
${ }^{127}$ Consultar o seguinte DVD: The Mythology of Star Wars with George Lucas and Bill Moyers. Films for the Humanities \& Sciences. 57min. 1999.

${ }^{128}$ CATHARINO, Alex. A Imaginação Moral em Star Wars. p. 221.
} 
ta anos, o mistério da origem de Vader como um mutilado e reconstituído Anakin Skywalker foi revelado ao público, que o transformou em uma lenda.

Conduzindo às entrelaçadas cenas de nascimento está um dos mais longos duelos jamais filmados, encenado contra o apocalíptico pano de fundo do sulfuroso planeta vulcânico de Mustafar. Lucas chamava essa luta feroz entre Anakin Skywalker e seu Mestre Jedi, Obi-Wan Kenobi, de "o ponto de inflexão de toda a série". O fogo oferece aqui uma sublime poesia elementar [...]. Disse Lucas que havia muito cultivada na cabeça uma imagem colorida do final de Sith, "monocromático em vermelho e negro". Os fervilhantes vermelhos e amarelos do grande rio de lava e suas cascatas (baseadas nas cataratas de Niágara) enchem os olhos. É uma visão do inferno ${ }^{129}$.

$[\ldots]$

É uma das mais apaixonantes cenas, jamais filmadas entre dois homens [...]. O drama pessoal é encenado contra um drama físico: altercando e lutando, Anakin e Obi-Wan caem sobre um painel de controle de uma grande usina de extração de minérios, que então deixa de funcionar bem e começa a desmoronar. Enquanto os dois correm e saltam para salvar suas vidas, vigas, passarelas e torres derretem e se esboroam na lava, demonstrando a fragilidade da civilização quando confrontada com o poder primal bruto da natureza. Lucas corta para a delirante destruição, em Coruscant, do Grande Salão Redondo do Senado Galáctico, com seus mil balcões em frias tonalidades de cinza e negro. Essa ruína geminada da arquitetura industrial e política é um espetáculo romântico épico [...]. A tempestuosa trilha sonora coral [...] tem o ímpeto implacável de uma missa sombria. A mixagem de som supervisionada por Lucas, é amedrontadora: uma tempestade de rugidos, silvos, explosões, tinidos e de sons aquáticos torna-se abruptamente vazia e silenciosa quando o braço e as pernas de Anakin são cortados em pleno ar. Ele cai pesadamente no chão, onde se arrasta como uma serpente, com demoníacos olhos amarelos, antes de pegar fogo e ser parcialmente incinerado.

${ }^{129}$ PAGLIA. Imagens Cintilantes. p. 190.
Mas todos esses horrores são transcendidos e no sereno final de Vingança dos Sith. O violento rio vermelho da emoção primitiva é esquecido, enquanto os gêmeos separados são entregues a seus pais adotivos, em paz diante de amplas paisagens idílicas de montanhas e de desertos galáxia afora. [...] “Expandam o nosso universo!", é a ordem de Lucas a seus artistas e técnicos. É um homem das máquinas, mas também um amante da natureza, sua astuta persona de genial serenidade disfarçando uma das mais potentes e obstinadas mentes da cultura contemporânea ${ }^{130}$.

A riqueza simbólica apresentada pelos espetáculos cinematográficos desenvolvidos por George Lucas nos seis filmes da série Star Wars é um artifício que devemos utilizar na árdua tarefa, conclamada por Russell Kirk, de unir a "imaginação moral à reta razão"131. Devemos lutar "contra o que seja estúpido, absurdo, errôneo e mau", como asseverou Ludwig von Mises, "com as armas do pensamento, não com a força bruta e a repressão $0^{\prime \prime 132}$. Mais uma vez, repetimos o conselho de F. A. Hayek quando ressaltou a missão que deverá ser aceita tanto por libertários quanto por conservadores na luta contra as desumanizadoras ideias e instituições coletivistas de nossa época:

O importante, agora, é que teremos de encontrar um consenso em torno de certos princípios e de nos libertar de alguns erros que pautaram a nossa conduta nas últimas décadas [...] Agora, é mais importante remover os obstáculos com que a insensatez humana obstruiu o nosso caminho e liberar a energia criadora dos indivíduos, do que inventar novos mecanismos para "guiá-los" e "dirigi-los" - criar condições favoráveis ao progresso, em vez de "planejar o progresso". A primeira necessidade é libertarmo-nos da pior forma de obscurantismo contemporâneo: aquela que procura persuadir-nos de que nossa conduta no passado recente foi, ou

\footnotetext{
${ }^{130}$ Idem. Ibidem., p. 192.

${ }^{131}$ KIRK. Um Epílogo Exortatório: Poderá a Geração Futura Redimir o Tempo? In: A Política da Prudência. p. 345.

${ }^{132}$ MISES. Liberalismo. p. 81.
} 
acertada, ou inevitável. Não nos tornaremos mais sábios enquanto não aprendermos que muito do que fizemos era pura tolice ${ }^{133}$.

As ideologias totalitárias de esquerda e de direita transformaram o século XX em uma terrível época de decadência espiritual, política e econômica com resultados desastrosos para a liberdade individual, destarte o impressionante aumento do progresso material. Em nossos dias ainda temos o dever moral de confrontar algumas formas ideológicas mais brandas de ameaças à liberdade individual, como

Crede naquilo que homens e mulheres de sabedoria, ao longo das eras, acreditaram em termos de fé e moralidade, e encontrareis uma base firme sobre a qual vos deveis postar enquanto os ventos da doutrina uivarem ao vosso redor.

O que é tudo isso - este mundo confuso de coisas materiais resplandecentes e de pavorosa decadência pessoal e social? Descobri que é um mundo real, não obstante os vícios: um mundo real, em que ainda podemos desenvolver e exercitar as virtudes possíveis da coragem, prudência, temperança e justiça; a própria fé, esperança e caridade. Sofrereis quedas no mundo, Deus sabe; mas também podereis gozar de triunfos. É um mundo em que tanta coisa precisa de ser feita que ninguém devia estar entediado.

Toda a criação que nos circunda é o jardim de que nós, humanos falíveis, fomos destinados a cuidar. Plantai algumas flores ou árvores, caso possais, e arrancai algumas ervas daninhas. Não creiais que a política lamentável de colocar-vos em primeiro lugar levar-vos-á às portas do Céu. Não deixeis de lembrar que a consciência é uma perpétua aventura. Não ignoreis a sabedoria das eras, a democracia dos mortos.

Aqueles dentre nós que aspiram a conservar a ordem, a justiça e a liberdade herdadas, nosso patrimônio de sabedoria, beleza e gentileza, têm um duro caminho pela frente - confesso. Muitas vozes declaram que a vida não vale a pena. Uma multidão de escritores, publicistas e membros da classe comumente chamada "intelectual" informam sombria-

\footnotetext{
${ }^{133}$ HAYEK. O Caminho da Servidão. p. 221.
}

mente que nós, seres humanos, não somos melhores do que macacos nus, e que a própria consciência é uma ilusão. Tais pessoas insistem em que a vida não tem propósito algum, a não ser a gratificação sensual; que a breve duração de nossa existência física é tudo o que há e o fim de tudo. Esses sofistas do século XX criaram nas escuras cavernas do intelecto um Mundo Inferior; e esforçam-se em nos convencer de que não há um sol - de que o mundo de maravilhamento e de esperança não existe em lugar algum, e nunca existiu. [...]

Tais doutrinas do desespero, vós, da geração que surge, devereis confrontar e refutar ${ }^{134}$.

Assim como o papel pedagógico das obras de fantasia mitopoética não deve ser subvalorizado, também, seria errôneo sobrevalorizar tais narrativas ficcionais, buscando mensagens subliminares além das alegorias explicitamente apresentadas ou das inúmeras metáforas que podem ser apropriadas para fins pedagógicos. No caso específico de Star Wars, o próprio George Lucas fez a seguinte advertência:

Outro aspecto destes filmes, que às vezes é esquecido, é que são vagamente frívolos, já que não se levam muito a sério. Eles tentam ser muito realistas e tudo mais, mas o objetivo é ter uma aventura hilariante e uma boa diversão. Às vezes as pessoas tentam ver mais do que está neles ou descartá-los como sem importância, mas a realidade está entre um extremo e o outro ${ }^{135}$.

Mais importante do que o arcabouço de imaginação moral existente na saga de filmes Star Wars é a importante função de tais narrativas como entretenimento. Acima de tudo, devemos apreciar tais obras pelo senso de beleza e de alegria que oferecem, não as instrumentalizando como meros suportes ideológicos. Que a Força esteja com vocês! cos

\footnotetext{
${ }^{134}$ KIRK. Um Epílogo Exortatório: Poderá a Geração Futura Redimir o Tempo? In: A Política da Prudência. p. 346-47.

${ }^{135}$ Declaração feita nos comentários de áudio ao filme O Retorno de Jedi.
} 